\title{
Structural Chemistry of Metal Coordination Complexes at High Pressure
}

\author{
Jeremiah P. Tidey, Henry L.S. Wong, Martin Schröder and Alexander J. Blake* \\ School of Chemistry, The University of Nottingham \\ University Park, Nottingham NG7 2RD, UK
}

\begin{abstract}
The application of pressures of up to about $10 \mathrm{GPa}$ may induce significant geometric, configurational, conformational and packing changes in molecular solids. This review highlights and describes recent advances in high pressure studies of coordination complexes, many of which have been conducted at synchrotrons or other central facilities. The main focus is on the wide range of geometric changes which occur with pressure. In some cases these changes have associated physical effects, and the review describes materials exhibiting negative linear compressibility, spin cross-over phenomena, magnetism and molecular conduction, as well as detailing the exciting possibilities for future developments in this area of research.
\end{abstract}




\section{Contents}

1. Introduction

2. Geometric, Coordinative, Conformational, Optical and other Changes with Pressure

2.1 Polymerisation of the binuclear $\mathrm{Cu}(\mathrm{II})$ complex $[\mathrm{guH}]\left[\mathrm{Cu}_{2}(\mathrm{OH})(\mathrm{cit})(\mathrm{gu})_{2}\right]\left(\mathrm{cit}^{4-}=\right.$ citrate; $\mathrm{gu}=$ guanidine) to form one-dimensional chains

2.2 Pressure-induced switching in binuclear $\mathrm{Cu}(\mathrm{II})$ complex $[\mathrm{guH}]_{4}\left[\mathrm{Cu}_{2}(\mathrm{cit})_{2}\right] \cdot 2 \mathrm{H}_{2} \mathrm{O}$ $\left(\mathrm{cit}^{4-}=\right.$ citrate, $\mathrm{gu}=$ guanidine $)$

2.3 Studies of three hydroxo-bridged binuclear $\mathrm{Cu}(\mathrm{II})$ complexes

2.4 Tuning an axial interaction in $\left[\mathrm{Cu}^{\mathrm{II}}(L\right.$-aspartate $\left.)\left(\mathrm{H}_{2} \mathrm{O}\right)_{2}\right]$

2.5 Effect of pressure on the binuclear $\mathrm{Cu}(\mathrm{II})$ complex $\left[\mathrm{Cu}_{2}\left(\mu_{2}-1,1^{\prime}-(1,3-\right.\right.$ phenylene $)$ bis $(4,4-$ dimethylpentane-1,3-dionato $\left.)_{2}(N \text {-methylmorpholine })_{2}\right]$

2.6 Multiple pressure-induced phenomena in $\left[\mathrm{PdCl}_{2}(1,4,7\right.$-trithiacyclononane)]

2.7 Pressure-induced $\pi \cdots \pi$ interactions and intramolecular deformation in $[\operatorname{Pd}(1,4,7-$ trithiacyclononane $\left.)\left(\mathrm{PPh}_{3}\right)_{2}\right]\left(\mathrm{PF}_{6}\right)_{2}$

2.8 Structure and bonding in the metallocenes $\mathrm{LiCp}, \mathrm{KCp}$ and $\mathrm{CsCp}\left(\mathrm{Cp}^{-}=\right.$cyclopentadienyl $)$

2.9 Structural factors controlling piezochromism in Ni(II) salicylaldoximato complexes

2.10 Structural and optical behaviour in the photomagnetic switching complex $\left[\mathrm{Y}(\mathrm{DMF})_{4}\left(\mathrm{H}_{2} \mathrm{O}\right)_{3}(\mu-\mathrm{CN}) \mathrm{Fe}(\mathrm{CN})_{5}\right] \mathrm{H}_{2} \mathrm{O}$

2.11 Phase transition and compressibility in [Co(5,10,15,20-tetraphenyl-12H, 23H-porphinate)

2.12 Phase transitions and conformational changes in $\left[\mathrm{Co}_{2}(\mathrm{CO})_{6}\left(\mathrm{XPh}_{3}\right)_{2}\right](\mathrm{X}=\mathrm{P}, \mathrm{As})$

2.13 High pressure studies of $\mathrm{Ru}_{3}(\mathrm{CO})_{12}$

2.14 Effects on intramolecular electron transfer in the mixed-valence complex $\left[\mathrm{Fe}_{3} \mathrm{O}\left(\mathrm{O}_{2} \mathrm{CC}\left(\mathrm{CH}_{3}\right)_{3}\right)_{6}(\mathrm{py})_{3}\right]($ py $=$ pyridine $)$

2.15 Effects of pressure (to $8 \mathrm{GPa}$ ) on unit cell parameters of trans-[ $\left[\mathrm{PtCl}_{2}(\text { dimethylsulfide })_{2}\right]$

2.16 Pressure-induced phase and structural changes in salts of $\left[\left\{\mathrm{SbCl}_{5}\right\}_{n}\right]^{2{ }^{-}}$

2.17 Effects of pressure on non-covalent interactions in (4-chloropyridinium) $)_{2}\left[\mathrm{CoX}_{4}\right](\mathrm{X}=\mathrm{Cl}$, $\mathrm{Br})$

2.18 Structure of $\left[\mathrm{Co}\left(\mathrm{NH}_{3}\right)_{5} \mathrm{NO}_{2}\right] \mathrm{Cl}_{2}$ to $3.38 \mathrm{GPa}$

2.19 Solvent ordering and other effects in wet Vitamin $\mathrm{B}_{12}$

2.20 Effects of pressure on the three-membered linear metal chain $\left[\mathrm{Co}_{3}(2,2\right.$ 'dipyridylamide $\left.{ }_{4} \mathrm{Cl}_{2}\right] \cdot \mathrm{CH}_{2} \mathrm{Cl}_{2}$

3. Complexes Exhibiting Negative Linear Compressibility

3.1 Large negative linear compressibility in $\left[\left(\mathrm{C}_{6} \mathrm{~F}_{5} \mathrm{Au}\right)_{2}(\mu\right.$-1,4-diisocyanobenzene $\left.)\right]$, $\mathrm{Zn}\left[\mathrm{Au}(\mathrm{CN})_{2}\right]_{2}, \mathrm{Ag}_{3}\left[\mathrm{Co}(\mathrm{CN})_{6}\right]$ and $\mathrm{KMn}\left[\mathrm{Ag}(\mathrm{CN})_{2}\right]_{3}$

4. Spin-crossover Complexes

4.1 Negative linear compression and spin-crossover in [Fe(dipyrido[3,2-a:2',3'$c$ ]phenazine $\left.)_{2}(\mathrm{NCS})_{2}\right]$ ·pyridine

4.2 Two Fe(II) spin-crossover complexes: $\left[\mathrm{Fe}(1,10 \text {-phenanthroline })_{2}(\mathrm{NCS})_{2}\right]$ and [Fe(2,2'-bi-4,5-dihydrothiazine $\left.)_{2}(\mathrm{NCS})_{2}\right]$

4.3 The structure of $\left[\mathrm{Fe}(\mathrm{N}-2 \text { ' - pyridylmethylene-4-aminoterphenyl })_{2}(\mathrm{NCS})_{2}\right]$ to $0.4 \mathrm{GPa}$

4.4 Absence of spin-crossover transition with pressure in the complex [Mn(III)( pyrol $_{3}$ tren)]

4.5 A pressure-induced two-step spin transition in [Fe(6,6'-bis(amino-2-pyridyl)-2,2'bipyridine $\left.)(\mathrm{NCS})_{2}\right]$

4.6 Gradual spin-crossover transitions in [\{Fe(2,6-bis(pyrazol-3-yl)pyridine $\left.)(\mathrm{NCS})_{2}\right\}_{2}\left(4,4^{\prime}-\right.$ bipy)] $2 \mathrm{MeOH}$

4.7 Neutron powder diffraction studies on [ $\mathrm{Fe}\left(\mathrm{N}-2^{\prime}\right.$-pyridylmethylene-4-(phenylazo)aniline $\left.)_{2}(\mathrm{NCS})_{2}\right]$ and $\left[\mathrm{Fe}\left(\mathrm{N}-2^{\prime} \text { '-pyridylmethylene-4-aminobiphenyl }\right)_{2}(\mathrm{NCS})_{2}\right]$

5. Molecular Magnetic Materials

$5.1 \quad$ High-pressure structural and magnetic studies on two $[\mathrm{Mn}]_{6}$ clusters

5.2 High pressure effects on a trimetallic $\mathrm{Mn}(\mathrm{II}) / \mathrm{Mn}(\mathrm{III})$ single molecule magnet

5.3 Pressure-induced switching of the Jahn-Teller axis in $\left[\mathrm{Mn}_{12} \mathrm{O}_{12}\left(\mathrm{O}_{2} \mathrm{CCH}_{2}{ }^{\mathrm{t}} \mathrm{Bu}\right)_{16}\left(\mathrm{H}_{2} \mathrm{O}\right)_{4}\right] \mathrm{CH}_{2} \mathrm{Cl}_{2} \cdot \mathrm{MeNO}_{2}$

5.4 A high-pressure structural study of two oxo-bridged $\mathrm{Mn}(\mathrm{III}) / \mathrm{Mn}(\mathrm{IV})$ complexes

5.5 Combined magnetic and structural studies of the antiferromagnet $\left[\left(\mathrm{CH}_{3}\right)_{4} \mathrm{~N}\right]\left[\mathrm{MnCl}_{3}\right]$

5.6 A high pressure structural-magnetic study of the magnetic sponge $\left\{\left[\mathrm{Mn}(\mathrm{II})(\text { pyridazine })\left(\mathrm{H}_{2} \mathrm{O}\right)_{2}\right]\left[\mathrm{Mn}(\mathrm{II})\left(\mathrm{H}_{2} \mathrm{O}\right)_{2}\right]\left[\mathrm{Nb}(\mathrm{IV})(\mathrm{CN})_{8}\right] \cdot 3 \mathrm{H}_{2} \mathrm{O}\right\}_{n}$

6. Molecular Conducting Materials 
6.1 Pressure-induced transitions in the spin-Peierls compound $\alpha^{\prime}$-(BEDT-TTF $)_{2} \mathrm{Ag}(\mathrm{CN})_{2}$ (BEDT-TTF $=$ bis (ethylenedithio)tetrathiafulvalene)

6.2 Effects on the structure of the magnetic molecular conductor (BEDT-TTF) ${ }_{3} \mathrm{CuBr}_{4}$

6.3 Pressure-induced deformations in $\kappa-\left[(\mathrm{BEDT}-\mathrm{TTF})_{2} \mathrm{Cu}(\mathrm{NCS})_{2}\right]$, a superconducting charge-transfer salt

6.4 High pressure studies of the molecular wires $\left[\mathrm{M}(\mathrm{dpg})_{2}\right]\left(\mathrm{M}=\mathrm{Ni}, \mathrm{Pt} ; \mathrm{dpg}^{-}=\right.$ diphenylglyoximato $)$ and $\left[\mathrm{Pt}(\mathrm{dmg})_{2}\right]\left(\mathrm{dmg}^{-}=\right.$dimethylglyoximato $)$

6.5 Crystal structure of $\left[\left(\mathrm{C}_{2} \mathrm{H}_{5}\right)_{2}\left(\mathrm{CH}_{3}\right)_{2} \mathrm{~N}\right]\left[\mathrm{Pd}(\mathrm{dmit})_{2}\right]_{2}\left(\mathrm{dmit}^{2-}=1,3\right.$-dithiole-2-thione-4,5 dithiolate)

6.6 Effects of pressure on the intermolecular geometry of $\left[\mathrm{Au}(\mathrm{tmdt})_{2}\right]\left(\mathrm{tmdt}^{2-}=\right.$

7. Prospects for Future Research

8. Concluding Remarks

9. Acknowledgements

10. References

\section{Keywords:}

Synchrotron science

High pressure crystallography

Structural chemistry

Phase changes

Metal-organic complexes

Organometallic compounds

Metal complexes

Coordination compounds

Supramolecular chemistry 


\section{Introduction}

Chemical processes or compounds do not commonly experience pressures greater than a few hundred times atmospheric pressure. For example, the maximum pressure employed during the Haber-Bosch process does not usually exceed $c a .250$ atmospheres $(0.025 \mathrm{GPa})$, and at such pressures solids appear to be essentially incompressible. However, above $0.1 \mathrm{GPa}$ compression begins to exert observable and significant effects upon them. Diamond anvil cells (DACs), in particular the Merrill-Bassett design [1], are a typical choice for high pressure studies of metal coordination complexes and related compounds, and the experimental limitations associated with this design and the attempts to overcome these have been widely discussed, for example by Moggach et al. [2]. Using a spark eroder, a small hole, typically around $200 \mu \mathrm{m}$ in diameter, is drilled in a thin, pre-indented metal gasket; the gasket is subsequently placed between the culet faces of two diamond anvils to form the sample chamber. The anvils are supported on backing plates within a stainless steel cage equipped with Allen screws, the tightening of which applies pressure to a pressure transmitting medium (PTM) filling the sample chamber. This in turn transmits isotropic pressure to the sample, up to the hydrostatic limit of the PTM. Fluorescence spectroscopy [3] can be used to measure the pressure inside a diamond anvil cell via a small ruby sphere placed in the chamber alongside the compound to be studied. The ruby is excited by a laser and the resulting fluorescence is recorded and, since the position of the $R 1$ line is linearly dependent on pressure over a wide pressure range, the pressure applied within the diamond anvil cell can, therefore, be determined. Data are collected at a number of pressures in order to investigate the response of the sample to pressure, either to the point where the sample loses crystallinity or to the hydrostatic limit of the PTM. Apart from modifications to allow the diamond anvil cell to be accommodated on an X-ray diffractometer, the only other additional requirement for a high pressure X-ray crystallography laboratory is for a spark eroder for drilling the hole in a metal gasket to form part of the sample chamber.

The use of such equipment is not without its drawbacks, the most serious of which arise from the steel body of the DAC. This limits the region of reciprocal space that is accessible, thereby limiting the completeness and redundancy which can be achieved. The main effect on the structure analysis is to reduce the precision achievable for the geometric parameters, but structure solution by standard methods can be obstructed and refinements can become unstable and require the extensive use of restraints. An alternative method of structure solution, namely isomorphous replacement using the refined structural model from an earlier experiment, is generally applicable but this method is not always available, for example when a different phase appears as the result of a pressure-induced phase transition. Completeness and redundancy are less severely affected for samples which crystallise in higher-symmetry space groups, but data completeness of ca. $30 \%$ is nevertheless commonplace in these studies. Data quality is also restricted by strong diamond reflections and by gasket powder rings arising from components of the DAC, although advances in the software used for data reduction and processing can significantly mitigate their impact.

Instrumentation for in-house X-ray diffraction experiments continues to gain in capability. X-ray sources based upon microfocus, gradient vacuum or liquid-metal jet technologies can produce incident beams of 
exceptional brightness, and when coupled to increasingly sensitive and rapid detectors such instrumentation can support high pressure experiments. Despite these advances, synchrotron sources are brighter still, typically by orders of magnitude, making them invaluable for the most challenging studies. Even with crystals which diffract strongly, the greater speed of data collection possible at a synchrotron confers distinct advantages, with each dataset taking perhaps one hour or less to acquire. This compares with a minimum of several hours on an in-house instrument, with weakly diffracting samples taking considerably longer: the overall time required for a complete high pressure study can thus potentially be reduced from weeks to hours by the use of synchrotron sources. The use of synchrotron radiation provides other, indirect advantages to high-pressure studies, where pressures within the sample chamber of the DAC can drift as tension works through the system. Significantly reduced collection times involve both a decreased drift in pressure during the experiment and a shorter wait for the DAC to equilibrate following a pressure change, in effect allowing the user greater control over the pressure applied. Other advantages of working at synchrotron facilities include tuneable wavelengths, enhanced focussing and collimation of the X-ray beam, and the likely availability of specialised ancillary equipment for measuring pressures and drilling gaskets, negating the need for additional expensive equipment for in-house work.

Although the first high pressure study of a coordination complex, describing the compressibility and highpressure phase transition of the metalloporphyrin complex $[\mathrm{Co}(5,10,15,20$-tetraphenyl- $12 \mathrm{H}, 23 \mathrm{H}$ porphinate)], appeared in 1987 [4], it is comparatively recently that other such studies have emerged in significant numbers. There are now currently descriptions of around 50 relevant systems in the literature, two-thirds of which have appeared since 2009, when the broader area was reviewed [5]. The Cambridge Structural Database [6] (CSD version 5.35 November 2013) records a separate entry for each pressure point in a high pressure experiment and currently holds a total of 260 relevant entries. This review focusses on complexes which are predominantly mononuclear, at least at ambient pressure, but also includes a small number of binuclear and trinuclear species; it specifically excludes extended structures such as metal-organic frameworks which are the subject of a separate review [7].

Whereas high pressure studies of organic molecules might typically generate new phases by the rearrangement and modulation of intermolecular interactions, with bonding distances and valence angles largely unaffected, coordination compounds - where the metal geometry can be considerably more flexible can exhibit changes in bond distances which are an order of magnitude greater than those in organic compounds. Many high pressure single crystal diffraction studies on metal complexes have been undertaken to explore variations in specific physical phenomena such as polymorphism, magnetic behaviour, conductivity, colour and spin-crossover effects. These phenomena will be discussed in separate sections, but the majority of studies have focused on changes in geometry on increasing pressure, and this forms the primary focus of this review. 
The review begins by describing the broad range of structural changes which are observed on increasing pressure. These changes are largely geometric, but there are also examples of associated optical and other changes in property and function. We then highlight a small number of studies on the effects of pressure on negative linear compressibility, spin-crossover complexes and magnetic materials, including single-molecule magnets. Studies of molecular conductors comprise a small final section before the prospects for future developments are assessed.

\section{Geometric, Coordinative, Conformational, Optical and other Changes with Pressure}

This section surveys the relevant literature where the main emphasis has been on structural and related changes in coordination at the metal centre rather than on specific properties or function. The chemical systems studied are highly variable and, with the exception of work on a family of $\mathrm{Cu}$ (II) complexes, tend to comprise individually interesting but isolated examples rather than any systematic studies. Given the high level of experimental effort required to complete a successful high pressure study, this is unsurprising. The range of structural changes observed thus far is nevertheless extensive and impressive, with characteristic reductions in the lengths of unit cell parameters and intermolecular contacts accompanied by intramolecular changes to geometry, coordination number, conformation, solvent ordering, hydrogen bonding, degree of association, colour, phase or electronic structure.

\subsection{Polymerisation of the binuclear $\mathrm{Cu}(\mathrm{II})$ complex $[\mathrm{guH}]\left[\mathrm{Cu}_{2}(\mathrm{OH})(\mathrm{cit})(\mathrm{gu})_{2}\right]\left(\mathrm{cit}^{4-}=\right.$ citrate; $^{\mathrm{gu}}=$ guanidine) to form one-dimensional chains}

In the first of a number of studies on the high pressure behaviour of $\mathrm{Cu}(\mathrm{II})$ complexes, Moggach et al. [8] used Station 9.8 at the Daresbury Synchrotron Radiation Source (SRS) to investigate the binuclear $\mathrm{Cu}(\mathrm{II})$ complex $[\mathrm{guH}]\left[\mathrm{Cu}_{2}(\mathrm{OH})(\mathrm{cit})(\mathrm{Gu})_{2}\right]\left(\mathrm{cit}^{3-}=\right.$ citrate, gu = guanidine; Figure 1) which, under ambient conditions, packs as discrete molecules across a mirror plane with a series of long-range interactions (Figure 2a) between an unbound carboxylic oxygen and the $\mathrm{Cu}(\mathrm{II})$ centre of a neighbouring molecule $[\mathrm{Cu} \cdots \mathrm{O}=$

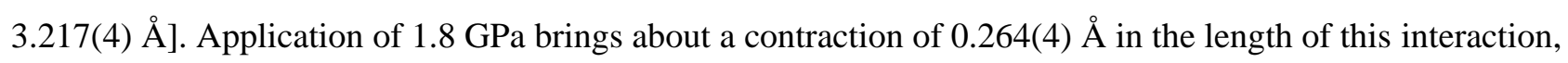
with the apical $\mathrm{O} \cdots \mathrm{Cu}$ donor interaction contracting by only $0.039(4) \AA$. At $2.9 \mathrm{GPa}$, there is a phase transition from Pnma to $P 2_{1} 2_{1} 2_{1}$ as two crystallographically independent $\mathrm{Cu} \cdots \mathrm{O}$ interactions of 2.879(7) and 2.610(6) $\AA$ are formed and mirror symmetry is lost (Figure 2b). As pressure is further increased to $4.2 \mathrm{GPa}$ there is another phase transition to space group $P 2_{1} / c$ in which neighbouring chains of the previously-formed polymer are no longer identical; one becomes slightly more symmetric, while in the other chain breaking of one of the previously-formed intermolecular $\mathrm{Cu} \cdots \mathrm{O}$ interactions takes place, coupled to a distortion in the symmetry of the shared apical oxygen in each binuclear unit. The authors draw attention to the reason for phase transitions in organic systems being one of minimising repulsion between atoms, but conclude that in this study the transitions seem to involve the avoidance of $\mathrm{Cu} \cdots \mathrm{O}$ interactions with lengths of around $3.0 \AA$, which appears to represent a region intermediate between intermolecular and intramolecular interactions. 


\subsection{Pressure-induced switching in binuclear $\mathrm{Cu}(\mathrm{II})$ complex $[\mathrm{guH}]_{4}\left[\mathrm{Cu}_{2}(\mathrm{cit})_{2}\right] \cdot 2 \mathrm{H}_{2} \mathrm{O}\left(\mathrm{cit}^{4-}=\right.$ citrate, gu = guanidine)}

Another SRS-based study published in 2010 [9] describes pressure studies on $[\mathrm{guH}]_{4}\left[\mathrm{Cu}_{2}(\mathrm{cit})_{2}\right] \cdot 2 \mathrm{H}_{2} \mathrm{O}(\mathrm{gu}=$ guanidine, $\mathrm{cit}^{4-}=$ citrate; Figure 3), which exhibits piezochromism. At ambient pressure each $\mathrm{Cu}(\mathrm{II})$ centre is coordinated primarily by four O-donors in a distorted tetrahedral geometry, supplemented by an intramolecular $\mathrm{Cu} \cdots \mathrm{O}$ contact to a more remote $\mathrm{O}$-donor in a carboxyl group. The application of pressure causes the length of this contact to decrease from 2.628(3) to 2.407(3) $\AA$ up to $2.2 \mathrm{GPa}$, resulting in a more square-based pyramidal geometry. These changes are accompanied by a gradual change in the colour of the crystal from blue to green as the relative energies and symmetries of the $d$-orbital manifold are modified. The contractions in the other $\mathrm{Cu}-\mathrm{O}$ bond lengths are negligible.

\subsection{Studies of three hydroxo-bridged binuclear $\mathrm{Cu}(\mathrm{II})$ complexes}

Prescimone et al. [10] subsequently published a study of three binuclear $\mathrm{Cu}$ (II) complexes in combination with a study of their magnetic behaviour. In these complexes, $\left[\mathrm{Cu}_{2}(\mathrm{OH})_{2}\left(\mathrm{H}_{2} \mathrm{O}\right)_{2}(\mathrm{tmen})_{2}\right]\left(\mathrm{ClO}_{4}\right)_{2}(\mathrm{tmen}=$ tetramethylethylenediamine; Figure $4 \mathrm{a}),\left[\mathrm{Cu}_{2}(\mathrm{OH})_{2}(\text { tben })_{2}\right]\left(\mathrm{ClO}_{4}\right)_{2}$ (tben $=$ di- $t$-butylethylenediamine; Figure $4 \mathrm{~b}$ ), and $\left[\mathrm{Cu}_{2}(\mathrm{OH})_{2}(\mathrm{bpy})_{2}\right]\left(\mathrm{BF}_{4}\right)_{2}$ (bpy $=2,2$ '-bipyridine; Figure $4 \mathrm{c}$ ), the equatorial planes of the $\mathrm{Cu}(\mathrm{II})$ centres, comprising two donors from the corresponding bidentate ligand and two bridging hydroxyl donors, are coplanar. $\left[\mathrm{Cu}_{2}(\mathrm{OH})_{2}\left(\mathrm{H}_{2} \mathrm{O}\right)_{2}(\text { tmen })_{2}\right]\left(\mathrm{ClO}_{4}\right)_{2}$ (Figure 5a) has an additional water molecule bound to each $\mathrm{Cu}(\mathrm{II})$ centre to give to square-based pyramidal geometries, while the $\mathrm{Cu}(\mathrm{II})$ centres in $\left[\mathrm{Cu}_{2}(\mathrm{OH})_{2}(\mathrm{bpy})_{2}\right]\left(\mathrm{BF}_{4}\right)_{2}$ are bridged both above and below the plane by $\mathrm{BF}_{4}{ }^{-}$moieties to give a $\mathrm{Cu}-\mathrm{F}-\mathrm{B}-\mathrm{F}-\mathrm{Cu}$ linkage. However, $\left[\mathrm{Cu}_{2}(\mathrm{OH})_{2}(\text { tben })_{2}\right]\left(\mathrm{ClO}_{4}\right)_{2}$ is less planar and has no additional ligating groups owing to the bulky tert-butyl groups on the tben ligand. Analysis of the data taken at the SRS showed very little effect of pressure on two of these systems, namely $\left[\mathrm{Cu}_{2}(\mathrm{OH})_{2}(\text { tben })_{2}\right]\left(\mathrm{ClO}_{4}\right)_{2}$ and $\left[\mathrm{Cu}_{2}(\mathrm{OH})_{2}(\mathrm{bpy})_{2}\right]\left(\mathrm{BF}_{4}\right)_{2}$, with the latter showing very little distortion owing to the bridging $\mathrm{BF}_{4}{ }^{-}$moieties which presumably give additional rigidity to the structure, although it should be mentioned that pressurisation to $0.9 \mathrm{GPa}$ does cause contraction in the length of the bridging $\mathrm{Cu}-\mathrm{O}$ bonds from $1.9198(12)$ to $1.77(3) \AA$. However, the effects of pressure on $\left[\mathrm{Cu}_{2}(\mathrm{OH})_{2}\left(\mathrm{H}_{2} \mathrm{O}\right)_{2}(\mathrm{tmen})_{2}\right]\left(\mathrm{ClO}_{4}\right)_{2}$ are more significant, with a number of changes being observed across the pressure range studied. As with the pressurisation of $\left.\left[\mathrm{Cu}_{2}(\mathrm{OH})_{2} \text { (tben }\right)_{2}\right]\left(\mathrm{ClO}_{4}\right)_{2}$ to $0.9 \mathrm{GPa}$, pressurisation of $\left[\mathrm{Cu}_{2}(\mathrm{OH})_{2}\left(\mathrm{H}_{2} \mathrm{O}\right)_{2}(\text { tmen })_{2}\right]\left(\mathrm{ClO}_{4}\right)_{2}$ to $1.2 \mathrm{GPa}$ causes the bridging $\mathrm{Cu}-\mathrm{O}-\mathrm{Cu}$ angles to become more acute and this leads to a contraction in the $\mathrm{Cu} \cdots \mathrm{Cu}$ distance and a decrease in antiferromagnetic exchange. The compression of intermolecular space results in a perchlorate counteranion drawing close to the bound water molecules of $\left[\mathrm{Cu}_{2}(\mathrm{OH})_{2}\left(\mathrm{H}_{2} \mathrm{O}\right)_{2}(\operatorname{tmen})_{2}\right]\left(\mathrm{ClO}_{4}\right)_{2}$ causing the $\mathrm{Cu}-\mathrm{Cu}-\mathrm{O}$ angle to deviate significantly from the value of $91.41(16)^{\circ}$ at ambient pressure to $80.4(7)^{\circ}$. Further application of pressure (to $2.5 \mathrm{GPa}$ ) brings about a phase transformation from $P 2_{1} / c$ to $P-1$ as the increased repulsion between water and perchlorate causes $50 \%$ of the binuclear moieties to lose one bound water molecule (denoted here as complex $\mathbf{2}$, complex $\mathbf{1}$ being that which retains both water molecules). As might be expected, this results in differing behaviours of the two now inequivalent binuclear species and, although both see a decrease in the $\mathrm{Cu} \cdots \mathrm{Cu}$ distance with pressure, there is also a much more 
pronounced contraction in complex 2 than in complex $\mathbf{1}[\Delta(\mathrm{Cu} \cdots \mathrm{Cu})=0.090(9)$ and 0.025(4) , respectively, Figure 5 (b), (c)], accompanied in complex 2 with a decrease in the $<\mathrm{Cu}-\mathrm{O}-\mathrm{Cu}$ bridging angles that is not observed for this system, with perchlorate anions observed to bind to the metal centres via an oxygen donor.

In all the complexes investigated, it was found that pressure causes the bridging $<\mathrm{Cu}-\mathrm{O}-\mathrm{Cu}$ angle to decrease, in turn decreasing antiferromagnetic exchange in $\left[\mathrm{Cu}_{2}(\mathrm{OH})_{2}\left(\mathrm{H}_{2} \mathrm{O}\right)_{2}(\mathrm{tmen})_{2}\right]\left(\mathrm{ClO}_{4}\right)_{2}$ and $\left[\mathrm{Cu}_{2}(\mathrm{OH})_{2}(\text { tben })_{2}\right]\left(\mathrm{ClO}_{4}\right)_{2}$ and increasing the ferromagnetic exchange in $\left[\mathrm{Cu}_{2}(\mathrm{OH})_{2}(\mathrm{bpy})_{2}\right]\left(\mathrm{BF}_{4}\right)_{2}$. The authors note that limited structural precision precludes the identification of this decrease in bridging angle as the direct reason for the decrease in antiferromagnetism in $\left[\mathrm{Cu}_{2}(\mathrm{OH})_{2}(\text { tben })_{2}\right]\left(\mathrm{ClO}_{4}\right)_{2}$, arguing that significant changes to the $\mathrm{Cu}-\mathrm{O}$ bond length could also give rise to such behaviour.

\subsection{Tuning an axial interaction in $\left[\mathrm{Cu}(\mathrm{II})(L\right.$-aspartate $\left.)\left(\mathrm{H}_{2} \mathrm{O}\right)_{2}\right]$}

In another example of compressible interactions involving the Jahn-Teller axis of $\mathrm{Cu}(\mathrm{II})$, the onedimensional coordination polymer $\left[\mathrm{Cu}(\mathrm{II})\left(\mathrm{L}\right.\right.$-aspartate) $\left.\left(\mathrm{H}_{2} \mathrm{O}\right)_{2}\right]$ (Figure 6) was studied at the SRS [11]. The structure under ambient conditions shows a square-based pyramidal geometry at $\mathrm{Cu}(\mathrm{II})$ with a distant carboxylic oxygen located at 2.925(2) $\AA$ and a water ligand at 2.311(2) $\AA$. Both of these interactions remain resistant to pressure up to $0.3 \mathrm{GPa}$, after which each undergoes a contraction up to $0.9 \mathrm{GPa}$ with the longrange carboxylic oxygen interaction contracting from 2.925(2) to 2.883(6) A. This axial interaction gradually contracts by a further $0.221(15) \AA$ to $6.8 \mathrm{GPa}$ while the $\mathrm{Cu}-\mathrm{O}_{\text {water }}$ distance decreases by only $0.077(10) \AA$ between ambient pressure and $6.8 \mathrm{GPa}$. On further pressurisation to $7.9 \mathrm{GPa}$ the distant carboxylic interaction shows a further discontinuous contraction with a sudden drop of $0.10(3) \AA$, accounting for $27 \%$ of the total contraction in this distance over the entire pressure range. This coincides with an equally sudden decrease in the length of the other axial $\mathrm{Cu}-\mathrm{O}$ bonded distance that accounts for $31 \%$ of its total contraction to $7.9 \mathrm{GPa}$ when the $\mathrm{Cu}-\mathrm{O}_{\text {water }}$ distance is $2.20(2) \AA$.

\subsection{Effect of pressure on the binuclear copper(II) $\left[\mathrm{Cu}_{2}\left(\mu_{2}-1,1^{\prime}-(1,3-\right.\right.$ phenylene $) b i s(4,4-$ dimethylpentane-1,3-dionato $\left.))_{2}(N \text {-methylmorpholine })_{2}\right]$}

The binuclear complex $\left[\mathrm{Cu}_{2}\left(\mu_{2}-1,1 \text { '-(1,3-phenylene)bis(4,4-dimethylpentane-1,3-dionato }\right)\right)_{2}(\mathrm{~N}$ methylmorpholine $)_{2}$ ] (Figure 7) was studied at pressures of up to $0.91 \mathrm{GPa}$ [12], above which crystallinity was lost. At ambient pressure, each $\mathrm{Cu}$ (II) centre has a slightly distorted square-based pyramidal geometry with two molecules of the dionate ligand bridging the two metal centres and providing the equatorial donor set with the $\mathrm{N}$-donor of an $\mathrm{N}$-methylmorpholine moiety $[\mathrm{Cu}-\mathrm{N}=2.536(6) \AA]$ at an axial position. The $\mathrm{O}$ donor of the $N$-methylmorpholine ligand of a neighbouring molecule then resides over the remaining axial coordination site at a distance of 3.364(7) $\AA$. Increasing the pressure on this complex led to a decrease in the axial bond lengths of $\mathrm{Cu}-\mathrm{N}$ and $\mathrm{Cu}-\mathrm{O}$ by $0.092(9)$ and $0.287(10) \AA$, respectively, with the equatorial donor set remaining largely unaffected by pressure, as commonly seen in such studies.

\subsection{Multiple pressure-induced phenomena in $\left[\operatorname{PdCl}_{2}(1,4,7\right.$-trithiacyclononane $\left.)\right]$}


From the studies above it can clearly be seen that coordination bonds vary greatly in their compressibility and, in addition to repulsive interactions, their structures offer opportunities for favoured interactions to contract significantly. Another example of this occurs in the case of $\left[\mathrm{PdCl}_{2}(1,4,7\right.$-trithiacyclononane) (Figure 8) in which the $\mathrm{Pd}(\mathrm{II})$ metal centre is bound in an $\mathrm{S}_{2} \mathrm{Cl}_{2}$ square plane [13]. The macrocycle binds facially with a third S-donor in an apical position [Pd $\cdots \mathrm{S}=3.159(10) \AA$ at ambient pressure]. These

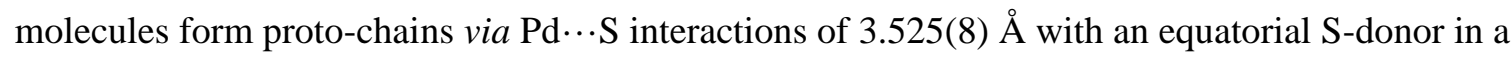
neighbouring molecule. By 4.25 GPa there has been a gradual contraction in these intramolecular and intermolecular Pd-S distances of 0.150(11) and 0.324(9) $\AA$, respectively. A small additional increase in pressure to $4.6 \mathrm{GPa}$ causes the system to undergo a sudden contraction in these distances, by a further 0.163(9) and 0.087(9) $\AA$, respectively, in a first order, isosymmetric, reversible phase transition to form a one-dimensional chain polymer of complexes having a distorted octahedral conformation, accompanied by the macrocycle distorting from a [234] to a [1233] conformation (Figure 9). At the transition, the colour of the crystal changes from orange to deep black. The interactions continue to contract with increasing pressure, but at a decreased rate to that before the transition, and no further discontinuities are observed to $7.68 \mathrm{GPa}$. High pressure data for $\left[\mathrm{PdCl}_{2}(1,4,7\right.$-trithiacyclononane) $]$ were obtained at the SRS, but subsequent studies on other members of the series $\left[\mathrm{MX}_{2}(1,4,7\right.$-trithiacyclononane $\left.)\right](\mathrm{M}=\mathrm{Pd}, \mathrm{Pt} ; \mathrm{X}=\mathrm{Cl}, \mathrm{Br}, \mathrm{I})$ have also used Diamond Light Source and in-house facilities [14].

\subsection{Pressure-induced $\pi \cdots \pi$ interactions and intramolecular deformation in $[\operatorname{Pd}(1,4,7-$ trithiacyclononane $\left.)\left(\mathbf{P P h}_{3}\right)_{2}\right]\left(\mathbf{P F}_{6}\right)_{2}$}

Using data collected on Beamline I19 at Diamond Light Source, Wong et al. [15] undertook a study of the complex $\left[\mathrm{Pd}\left(1,4,7\right.\right.$-trithiacyclononane) $\left.\left(\mathrm{PPh}_{3}\right)_{2}\right]\left(\mathrm{PF}_{6}\right)_{2}$ (Figure 10), in which the chloride $\pi$-donors of [ $\mathrm{PdCl}_{2}(1,4,7$-trithiacyclononane)] (see previous section) are replaced by phosphine $\pi$-acceptor ligands, resulting in a very short apical Pd $\cdots$ S interaction of only 2.868(2) $\AA$ at ambient pressure. Slipped-parallel four-fold phenyl embraces between pairs of molecules are disposed about an inversion centre. The effect of pressure on this assemblage of interactions was to bring about a large increase in ring overlap as the centroid-centroid offset distance falls from 4.195(10) ̊̊ at ambient pressure to 1.906(18) $\AA$ at $6.55 \mathrm{GPa}$ (Figure 11). An unprecedented deformation was observed at the ipso bridgehead carbon of the face-to-face interacting phenyl groups: the $\mathrm{P}-\mathrm{C}_{i p s o} \cdots \mathrm{C}_{\text {para }}$ pseudoangle of $169.6(4)^{\circ}$ at ambient pressure falls to $149.1(7)^{\circ}$ by $6.55 \mathrm{GPa}$. Hirshfeld surfaces and modelling of a constrained structure traced the source of this deformation to the formation of close $\mathrm{C}-\mathrm{H} \cdots \pi$ interactions within this embrace and the avoidance of very close, highly repulsive $\mathrm{H} \cdots \mathrm{H}$ interactions. In contrast to these changes, the application of pressure barely affected the length of the apical Pd $\cdots \mathrm{S}$ interaction, showing that in this system intramolecular deformation and the induction of $\pi \cdots \pi$ interactions are more facile processes.

\subsection{Structure and bonding in the metallocenes $\mathrm{LiCp}, \mathrm{KCp}$ and $\mathrm{CsCp}\left(\mathrm{Cp}^{-}=\right.$cyclopentadienyl)}

To better understand the bonding in metallocenes, Dinnebier et al. [16] used synchrotron powder X-ray diffraction taken on Beamline ID9 at the ESRF in Grenoble for high pressure studies of the one-dimensional 
systems $\mathrm{LiCp}, \mathrm{KCp}$ and $\mathrm{CsCp}\left(\mathrm{Cp}^{-}=\right.$cyclopentadienyl; Figure 12). They aimed to explore the effect of pressure on the behaviour of the bend angle describing the mutual inclination of the $\mathrm{Cp}$ rings. Only limited discussion of the CsCp structure was possible owing to the limitation of the data obtained. Several factors were found to affect this angle, such as ionic size, polarisability, lone pairs on the metal and the size of the ligands [17-19]. It was also suggested that attractive interactions between the ligands themselves plays a role [20]. At ambient pressure, the systems pack in polymeric $[\mathrm{M}-\mathrm{Cp}]_{\infty}$ chains: in $\mathrm{LiCp}$ the bend angle is $0^{\circ}$ and so the chains are linear, but in $\mathrm{KCp}$ where the bend angle $44.70^{\circ}$ the chains run in a zigzag fashion. In both cases, increased pressure reduces the $\mathrm{M}-\mathrm{Cp}$ distances, more so for the longer $\mathrm{K}-\mathrm{Cp}$ distance. For $\mathrm{LiCp}$, increased pressure did not alter the bend angle and the system remained linear, but for KCp it initially increased with pressure. This phenomenon was attributed to packing effects, with a greater bend allowing denser packing via interchain $\eta^{1}$ - and $\eta^{2}$ - bonding interactions between metal centres and $\mathrm{Cp}^{-}$molecules, the optimum value for which is determined by the shortest $\mathrm{C} \cdots \mathrm{C}$ distances between rings in adjacent chains.

\subsection{Structural factors controlling piezochromism in nickel salicylaldoximato complexes}

The high pressure behaviour of two Ni(II) salicylaldoximato complexes (Figure 13) were reported in a study by Byrne et al. [21]. Although planar molecules of [Ni(3-fluoro-salicylaldoximato) ${ }_{2}$ ] stack along the $c$ axis to give one-dimensional chains via $\mathrm{Ni} \cdots \mathrm{Ni}$ interactions [3.1942(4) $\AA$ ] , the pressure-induced contraction of this distance did not engender conductivity as was observed for $\left[\mathrm{Ni}\left(\mathrm{dmg}_{2}\right]\left(\mathrm{dmg}^{-}=\right.\right.$dimethylglyoximate), despite $\mathrm{Ni} \cdots \mathrm{Ni}$ distances of 2.822(2) $\AA$ at $5.4 \mathrm{GPa}$ for [Ni(3-fluoro-salicylaldoximato) 2 ] and $2.82 \AA$ at 7.4 $\mathrm{GPa}$ for $\left[\mathrm{Ni}(\mathrm{dmg})_{2}\right]$ [22]. Reversible green-red piezochromism is observed at $5 \mathrm{GPa}$ for both [Ni(3-fluorosalicylaldoximato $)_{2}$ and [Ni(3-methoxy-salicylaldoximato $)_{2}$ ]. However, [Ni(3-methoxy-salicylaldoximato $)_{2}$ ] does not form one-dimensional $\mathrm{Ni} \cdots \mathrm{Ni}$ chains. This, together with the observation that the UV/vis spectrum changes very little between solution and solid phases, supports the contention that piezochromism does not arise from stronger intermolecular effects. Rather, the process was attributed to marginal compressions of $\mathrm{Ni}-\mathrm{N}$ and $\mathrm{Ni}-\mathrm{O}$ bond lengths, which were shown by TD-DFT calculations to have a great impact on the energy of the Ni $d\left(x^{2}-y^{2}\right)$ orbital. This conclusion is reinforced by the calculations replicating the observed pressure-induced shift in the Laporte-forbidden $d\left(z^{2}\right) \rightarrow d\left(x^{2}-y^{2}\right)$ transition.

\subsection{Structural and optical behaviour in the photomagnetic switching complex $\left[\mathrm{Y}(\mathrm{DMF})_{4}\left(\mathrm{H}_{2} \mathrm{O}\right)_{3}(\mu-\right.$ $\left.\mathrm{CN}) \mathrm{Fe}(\mathrm{CN})_{5}\right] \cdot \mathrm{H}_{2} \mathrm{O}$}

A study of photoswitching in $\left[\mathrm{Y}(\mathrm{DMF})_{4}\left(\mathrm{H}_{2} \mathrm{O}\right)_{3}(\mu-\mathrm{CN}) \mathrm{Fe}(\mathrm{CN})_{5}\right] \cdot \mathrm{H}_{2} \mathrm{O}$ (Figure 14) revealed reversible piezochromism [23]: the complex is pale yellow at ambient pressure, becomes more orange towards 3.68 $\mathrm{GPa}$ and finally takes on a strong burgundy colour at 7.60 GPa. Single crystal data were collected using a laboratory source with a view to comparing the structures at high pressure with the crystal structure of the photo-excited state. A monoclinic to triclinic phase transition between 3.68 and $7.60 \mathrm{GPa}$ is accompanied by a doubling of the $b$ axis. No high pressure structure could be determined beyond $0.7 \mathrm{GPa}$, but unit cell parameters were determined for the monoclinic phase up to $3.68 \mathrm{GPa}$ and for the triclinic phase at 7.60 GPa. Even at $0.7 \mathrm{GPa}$ some notable changes were observed, including a number of changes of $c a .0 .1-0.2 \AA$ in the 
lengths of the $\mathrm{C} \equiv \mathrm{N}$ and metal-ligand bonds. Interestingly, most of these are elongations, with increases of 0.17(4) $\AA$ in the bridging $\mathrm{C} \equiv \mathrm{N}$ distance and 0.21(6) $\AA$ in a terminal $\mathrm{C} \equiv \mathrm{N}$ distance showing evidence of increased $\pi$ back-bonding; five out of the six $\mathrm{Fe}-\mathrm{C}$ distances also increase between ambient pressure and 0.7 GPa despite there being only negligible intramolecular contractions elsewhere. The proposed mechanism for the colour change involves charge transfer via the bridging cyanide moiety: this could be expected to bring about an increase in the $\mathrm{Fe}-\mathrm{C}$ bond distance owing to an increase in the size of the metal centre and a reduction in its charge, the latter conferring an increase in $\pi$ back-bonding.

\subsection{Phase transition and compressibility in the metalloporphyrin $(5,10,15,20$-tetraphenyl-12 $H$, $23 H$-porphinato)cobalt(II)}

In 1987, Hazen et al. [4] investigated [Co(L)] $\left(\mathrm{L}^{2-}=5,10,15,20\right.$-tetraphenyl-12H,23H-porphinate; Figure 15) at pressures of up to $0.9 \mathrm{GPa}$ and identified a tetragonal to triclinic phase transition at $0.49 \mathrm{GPa}$ which is associated with a significant increase in the compressibility of the system. Although detailed structural data were not obtained in this study, the authors quite reasonably propose that the compression is predominantly intermolecular owing to the nature of the packing in the low pressure phase, the anisotropy in axial compression and comparison of the axial compression with that of systems containing similar intermolecular contacts and packing. Furthermore, they conclude that the decrease in symmetry is directly linked to the increase in compressibility as, in losing the symmetry constraints of the tetragonal cell, molecules gain "compressional degrees of freedom", as exemplified in the case of $\mathrm{ReO}_{3}[24,25]$.

\subsection{Phase transitions and conformational changes in $\left[\mathrm{Co}_{2}(\mathrm{CO})_{6}\left(\mathrm{XPh}_{3}\right)_{2}\right](\mathrm{X}=\mathrm{P}, \mathrm{As})$}

Casati et al. investigated the effect of pressure on two isomorphous, isostructural systems $\left[\mathrm{Co}_{2}(\mathrm{CO})_{6}\left(\mathrm{XPh}_{3}\right)_{2}\right]$ ( $\mathrm{X}=\mathrm{P}, \mathrm{As}$; Figure 16), both of which exhibit a phase transition induced by low temperature or high pressure $[26,27]$. The phase change allows the release of compressional strain and involves the breaking of the inversion symmetry at the centre of the molecules, which previously constrained them to be perfectly staggered. This brings about a change in space group from $R-3$ to $R 3$ as the $c$ axis doubles. This process reduces the intermolecular steric clash between neighbouring phenyl groups that are forced towards the carbonyl moieties, causing them to rotate and bend away. This in turn gives rise to intramolecular steric clashing between the two sets of carbonyl ligands within the molecule, causing these to also bend away from the approaching phenyl groups. After the phase transition, which occurs at $1.3 \mathrm{GPa}$ for $\left[\mathrm{Co}_{2}(\mathrm{CO})_{6}\left(\mathrm{PPh}_{3}\right)_{2}\right]$ and at $0.3 \mathrm{GPa}$ for $\left[\mathrm{Co}_{2}(\mathrm{CO})_{6}\left(\mathrm{AsPh}_{3}\right)_{2}\right]$, the $\mathrm{C}-\mathrm{Co}-\mathrm{Co}-\mathrm{C}$ torsion angle rapidly falls towards $\mathrm{ca} .20^{\circ}$, bringing about an elongation of the $\mathrm{Co}-\mathrm{Co}$ bond from 2.67(1) to 2.72(1) $\AA$, in agreement with DFT modelling of the eclipsing. The elongation is accompanied by a shift of the whole molecule along the $c$ axis, resulting in alternating more-tightly and less-tightly packed intermolecular sextuple embraces of the $\mathrm{XPh}_{3}$ groups. Although the same phase transition is observed under cooling, the extent of staggering that is reached is significantly lower, only decreasing to $55.57(4)^{\circ}$ in $\left[\mathrm{Co}_{2}(\mathrm{CO})_{6}\left(\mathrm{PPh}_{3}\right)_{2}\right]$ at $120 \mathrm{~K}$.

\subsection{High pressure studies of $\mathrm{Ru}_{3}(\mathrm{CO})_{12}$}


Another system containing unsupported $\mathrm{M}^{\cdots \cdots} \mathrm{M}$ interactions, namely the homoleptic $\mathrm{Ru}_{3}(\mathrm{CO})_{12}$ (Figure 17) was studied by Slebodnick et al. [28]. At ambient pressure, the complex is in the anticuboctahedral form and was investigated to see whether pressure could bring about a transformation to the more dense icosahedral structure. Despite the $\Delta$ (Pressure $\mathrm{x}$ Volume) energy input to the system far exceeding the calculated energy difference between the two systems, no phase transition was observed to $8.14 \mathrm{GPa}$, leading the authors to conclude that there must be no symmetry coordinate linking the structures in the solid state. The other effects of pressure on the system essentially involve reducing interstitial space, with the $\mathrm{Ru}$ " $\mathrm{Ru}$ interactions decreasing in length by 0.080(15) Å and small changes in the geometries at the metal centres. No other bonded interactions were observed to change significantly. The authors note that $\mathrm{Ru}_{3}(\mathrm{CO})_{12}$, with a bulk modulus of only $6.6 \mathrm{GPa}$, is particularly soft in comparison to materials such as $\mathrm{NaCl}$ (bulk modulus 25 $\mathrm{GPa})$, quartz (37 GPa), ceramics (50-300 GPa) and diamond (440 GPa). However, the value of $6.6 \mathrm{GPa}$ is broadly comparable to values seen for other metal-organic molecular compounds.

\subsection{Effects on intramolecular electron transfer in the mixed-valence complex $\left[\mathrm{Fe}_{3} \mathrm{O}\left(\mathrm{O}_{2} \mathrm{CC}\left(\mathrm{CH}_{3}\right)_{3}\right)_{6}\right] \cdot\left(\mathrm{C}_{5} \mathrm{H}_{5} \mathrm{~N}\right)_{3}$}

Scheins et al. contrasted the effects of temperature and pressure on intramolecular electron transfer in mixedvalence complexes [29]. The trinuclear complex $\left[\mathrm{Fe}_{3} \mathrm{O}\left(\mathrm{O}_{2} \mathrm{CC}\left(\mathrm{CH}_{3}\right)_{3}\right)_{6}\right] \cdot\left(\mathrm{C}_{5} \mathrm{H}_{5} \mathrm{~N}\right)_{3}$ (Figure 18) contains two Fe centres in the +3 and one in the +2 oxidation state, giving rise to the potential for two different sets of $\mathrm{Fe}-\mathrm{O}$ bond lengths. This complex was considered as a target to investigate the use of pressure as a method of valence trapping whereby changes in the packing might bring about an increase in the energy barrier to the electron transfer between the different metal centres; indeed, it has been shown previously that cooling can have this effect on the system [30]. In the high pressure experiment, no phase transition is observed to 1.2 $\mathrm{GPa}$, nor is there total valence trapping as tracked by the variation in bond lengths from the Fe centres to the central $\mu_{3}$-oxido ligand. At ambient pressure, one $\mathrm{Fe}-\mathrm{O}$ bond is significantly shorter than the other two, and this shows very little response to increased pressure. The other two $\mathrm{Fe}-\mathrm{O}$ bonds, which differ at ambient pressure by $c a$. $0.05 \AA$, maintain this difference until $c a$. $0.4 \mathrm{GPa}$. At this pressure the difference begins to reduce, such that the lengths cross over at $c a$. $0.5 \mathrm{GPa}$, and by $0.74 \mathrm{GPa}$ a separation of $c a .0 .12 \AA$ results, indicative of a degree of valence trapping. No further increase in valence-trapping is observed as the pressure is raised to $0.96 \mathrm{GPa}$. The extended structure contains stacks of the ligated pyridyl moieties and in the temperature-dependence study there is an expansive rotation as valence trapping is observed. Analysis of the interplanar separations between these ligated pyridyl moieties in the high pressure structures shows that the application of pressure leads to a contraction in stacking distances, preventing this expansive rotation and providing a probable mechanism for the suppression of a phase transition.

\subsection{Effects of pressure (to $8 \mathrm{GPa}$ ) on unit cell parameters of trans-PtCl${ }_{2}$ (dimethylsulfide)}

Hansson et al. have analysed the proportion and relative energies of cis and trans isomers of complexes $\mathrm{PtX}_{2} \mathrm{~L}_{2}$ found in the CSD, and have reported the unit cell parameters for trans- $\mathrm{PtCl}_{2}(\mathrm{dms})_{2}(\mathrm{dms}=$ dimethylsulfide; Figure 19) to $8.0 \mathrm{GPa}$, determined by powder X-ray diffraction [31]. They found no phase 
transitions and only smooth contractions in unit cell lengths, with an overall decrease of $26 \%$ in unit cell volume, and a smooth increase in the $\beta$ angle of the monoclinic unit cell.

\subsection{Pressure-induced phase and structural changes in salts of $\left[\left\{\mathrm{SbCl}_{5}\right\}_{n}\right]^{2 n-}$}

At ambient pressure the structure of $\left[\left(\mathrm{CH}_{3}\right)_{2} \mathrm{NH}\left(\mathrm{CH}_{2}\right)_{2} \mathrm{NH}_{3}\right]\left[\mathrm{SbCl}_{5}\right]$ consists of fully-ordered $\left[\left(\mathrm{CH}_{3}\right)_{2} \mathrm{NH}\left(\mathrm{CH}_{2}\right)_{2} \mathrm{NH}_{3}\right]^{2+}$ cations and distorted square pyramidal $\left[\mathrm{SbCl}_{5}\right]^{2-}$ anions. This salt was studied by Bujak and Angel [32] to a pressure of $4.0 \mathrm{GPa}$ using in-house laboratory equipment to investigate the effects of pressure on the anions, which are known to adopt a number of different bonding geometries [33-35]. The anions form chains parallel to [001], with the equatorial $\mathrm{Sb}-\mathrm{Cl}$ bond of one unit directed towards the base of its neighbour [ $\mathrm{Sb} \cdots \mathrm{Cl}=3.667(2) \AA$; Figure 20]. The organic cations occupy the voids between inorganic polyhedra, with which they form hydrogen bonds that strongly influence the $\mathrm{Sb}-\mathrm{Cl}$ bond lengths. These vary from ca. $2.4 \AA$ for $\mathrm{Sb}-\mathrm{Cl}$ units not involved in hydrogen bonding to 2.947(6) $\AA$ for ones that form a hydrogen bond to the tertiary ammonium group. Pressure has little effect on the shorter intramolecular $\mathrm{Sb}-\mathrm{Cl}$ distances, but much greater effect on the intermolecular $\mathrm{Sb} \cdots \mathrm{Cl}$ interaction. The low temperature study reveals only small changes to bond lengths and no phase transitions down to $15 \mathrm{~K}$, whereas pressures of only $0.55 \mathrm{GPa}$ bring about a significant contraction in the intramolecular $\mathrm{Sb} \cdots \mathrm{Cl}$ interaction of $0.173(7) \AA$ to 3.509(3) A. Further compression to $1.00 \mathrm{GPa}$ causes a $P 2_{1} / c \rightarrow P 2_{1} / n$ phase transition that involves the doubling of the $a$ axis as pairs of previously crystallographically-equivalent $\mathrm{Sb} \cdots \mathrm{Cl}$ interactions give alternating interactions of 3.302(5) and 3.558(5) A. The authors consider the shorter of these two interactions of $c a$. $3.3 \AA$ to constitute a bridging bond, the other remaining non-bonding. The phase transition can be said to result in the formation of $\left[\mathrm{Sb}_{2} \mathrm{Cl}_{10}\right]^{4-}$ units, with the lone pair that previously occupied the octahedral corner on the underside of the square pyramidal coordination sphere becoming more $s$-type in character. This lone pair appears to remain stereochemically active to some extent, as evidenced in the distortion of the resulting octahedral coordination complex. After this phase transition, the system compresses smoothly, with the long, non-bonded interaction compressing more readily than the bridging bond to a value below the threshold previously defined for a bonding interaction and reaching 3.297(5) $\AA$ at 3.10 GPa. Despite this, the two bonds remain distinct across the pressure range studied [at $4.00 \mathrm{GPa}, \mathrm{Sb} \cdots \mathrm{Cl}_{\text {non-bonding }}=3.238(8) \AA$, $\mathrm{Sb} \cdots \mathrm{Cl}_{\text {bridging }}=3.080(6) \AA$ ] . Compressing the salt to $3.10 \mathrm{GPa}$ therefore leads to $\left\{\left(\mathrm{SbCl}_{5}\right)_{n}\right\}^{2 n-}$ chains of corner-sharing $\left[\mathrm{SbCl}_{6}\right]^{3-}$ octahedra. Despite the formation of bridges between polyhedra, the tilt angle between them, as defined by the tilt between planes of the equatorial donors, is reported as remaining largely unchanged.

Bujak and Angel undertook a study [36] of $\left[\left(\mathrm{CH}_{3}\right)_{2} \mathrm{NH}_{2}\right]_{2}\left[\mathrm{SbCl}_{5}\right]$, in which the packing comprises ordered organic cations located in voids between chains of inorganic anions which interact via different types of hydrogen bonds involving cross-linking of inorganic chains. Instead of packing as distinct $\left[\mathrm{SbCl}_{5}\right]^{2-}$ moieties, the inorganic components in this salt form a zigzag chain of corner-sharing distorted $\left[\mathrm{SbCl}_{6}\right]^{2-}$ octahedra (Figure 21), although the $\mathrm{Sb} \cdots \mathrm{Cl}$ interactions span a wide range of distances, from 2.404(1) $\AA$ (for the interaction involving the least strongly hydrogen-bonded Cl centre) to 3.257(1) $\AA$ (for one shared with a neighbouring moiety and involved in hydrogen bonding to the cation). High pressure structure determination 
was precluded as pressures of less than $0.5 \mathrm{GPa}$ caused a first-order phase transition that destroyed the crystal. Raman spectroscopy was used in a bid to gain further insight into this behaviour and it was found that by $0.44(5) \mathrm{GPa}$ the phase transition was complete. Low temperature single crystal X-ray diffraction confirms that cooling brings about a contraction in the length of the $\mathrm{H}^{\cdots} \mathrm{Cl}$ hydrogen-bonding interactions at bridged chlorides between $\mathrm{Sb}$ centres, and this in turn causes an elongation in the $\mathrm{Sb}-\mathrm{Cl}$ bond length from 3.257(1) to 3.3370(14) $\AA$. In previous work on $\left[\left(\mathrm{CH}_{3}\right)_{2} \mathrm{NH}\left(\mathrm{CH}_{2}\right)_{2} \mathrm{NH}_{3}\right]\left[\mathrm{SbCl}_{5}\right]$ [32] it was observed that $\mathrm{Sb}$... Cl interactions of $c a$. $3.4 \AA$ appeared to be relatively unstable. Increases in pressure would be expected to enhance hydrogen bonding and extend the bridging $\mathrm{Sb} \cdots \mathrm{Cl}$ bonding interactions into this "unstable region" and this might be a likely cause for the observed degradation of the crystal.

\subsection{Effects of pressure on non-covalent interactions in (4-chloropyridinium) ${ }_{2}[\mathrm{CoX}](\mathrm{X}=\mathrm{Cl}, \mathrm{Br})$}

Espallargas et al. undertook the study of two isostructural systems of (4-chloropyridinium) ${ }_{2}[\mathrm{CoX} 4](\mathrm{X}=\mathrm{Cl}$, $\mathrm{Br}$ ) [37] enabling them to explore the effect of pressure on a number of interactions. The formation of strong $\mathrm{N}-\mathrm{H} \cdots \mathrm{X}_{2} \mathrm{Co}$ and $\mathrm{Co}-\mathrm{X} \cdots \mathrm{Cl}-\mathrm{C}$ interactions in this structure give rise to tape motifs throughout the lattices (Figure 22). These interact with one another via $\pi \cdots \pi, \mathrm{Co}-\mathrm{X} \cdots \mathrm{Cl}-\mathrm{C}$ and $\mathrm{C}-\mathrm{Cl} \cdots \mathrm{Cl}-\mathrm{C}$ interactions distinct from those that form the tapes. Although in each case there are two types of hydrogen bonding, the longer one appeared less compressible (and therefore stronger) with the $\left[\mathrm{CoBr}_{4}\right]^{2-}$ than with $\left[\mathrm{CoCl}_{4}\right]^{2-}$, whereas the shorter hydrogen bonds are barely compressed. These hydrogen bonding interactions were in turn found to be less compressible than the $\pi \cdots \pi$ and $\mathrm{C}-\mathrm{Cl} \cdots \mathrm{Cl}-\mathrm{C}$ interactions, while the $\left[\mathrm{CoX}_{4}\right]^{2-}$ anion responds to pressure by distorting from ideal tetrahedral geometry.

\subsection{Structure of $\left[\mathrm{Co}\left(\mathrm{NH}_{3}\right)_{5} \mathrm{NO}_{2}\right] \mathrm{Cl}_{2}$ to $3.38 \mathrm{GPa}$}

As part of a series of papers studying the non-covalent interactions in $\left[\mathrm{Co}\left(\mathrm{NH}_{3}\right)_{5} \mathrm{NO}_{2}\right]^{2+}$ complexes [38, 39], Boldyreva et al. reported the high pressure structure of $\left[\mathrm{Co}\left(\mathrm{NH}_{3}\right)_{5} \mathrm{NO}_{2}\right] \mathrm{Cl}_{2}$ to $3.38 \mathrm{GPa}[40,41]$. The $\left[\mathrm{Co}\left(\mathrm{NH}_{3}\right)_{5} \mathrm{NO}_{2}\right]^{2+}$ cation (Figure 23) shows several responses to the application of pressure: between ambient pressure and $3.38 \mathrm{GPa}$ the $\mathrm{N}$ bound $\mathrm{Co}-\mathrm{NO}_{2}$ distance contracts by 0.015 (4) $\AA$ from $1.920(3)$ to $1.905(3) \AA$; the $\mathrm{Co}-\mathrm{NH}_{3}$ bond trans to the nitro group barely changes and the remaining $\mathrm{Co}-\mathrm{NH}_{3}$ bonds show similar

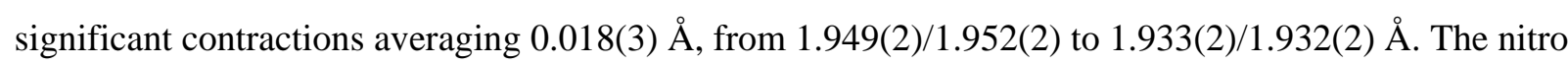
group rotates with respect to the mutually cis ammonia moieties, and the $\mathrm{N}-\mathrm{O}$ bond length increases slightly in length from 1.231(2) to $1.240(2) \AA$, possibly via a slight contraction to $1.225(2) \AA$ at $0.25 \mathrm{GPa}$. The authors attribute the anisotropy in the structural distortions to the effects of $\mathrm{N}-\mathrm{H}^{\cdots} \mathrm{Cl}^{-}$and $\mathrm{N}-\mathrm{H} \cdots \mathrm{O}$ hydrogen bonds and to $\mathrm{Cl}^{-} \ldots \mathrm{O}$ interactions.

\subsection{Solvent ordering and other effects in wet Vitamin B12}

In an exemplary case of high pressure increasing the quality of the crystal structure obtained in an experiment, Fabbiani et al. published work on the behaviour of wet vitamin $\mathrm{B}_{12}$ (Figure 24) at 1.0 GPa [42]. Although this work also gave rise to the observation of pressure-induced changes in the structure of the molecule itself, the most striking effect was that of solvent ordering. An ambient structure determination was 
first carried out on a crystal grown in situ in a capillary, confirming the structure previously reported in 1964 [43], albeit to a higher quality. As before, a great deal of disorder was observed for the water molecules located in the large solvent-accessible channels that run throughout the structure and in the pockets that branch off from these. For the high pressure study, a second crystal was grown in situ from a super-saturated solution in the DAC. Application of pressure to $1.0 \mathrm{GPa}$ brought about an $11 \%$ decrease in the cell volume, reducing the total solvent-accessible volume of the channel and pockets by $28 \%$. This resulted in extensive ordering of the water within these regions, allowing more of the water-related electron density to be accurately modelled as opposed to use of the SQUEEZE routine [44] in PLATON [45], as was the case for the ambient pressure structure. A further effect of pressure on the structure was to cause one of the side chains on the corrin ring to rotate, which in turn appeared to hinder the movement of water between pockets and channels thus assisting the ordering of the water molecules. No viable data collection could be carried out upon decompression because of crystal degradation. This is possibly attributed to the slow relaxation of the pressure-induced rotation of one of the side chains which in part closes the pockets off from the channels at high pressure. As increasing pressure causes ordering and localisation of the water in the channels and pockets (Figure 25), it could be said that decreasing the pressure allows the water to regain freedom of movement and may bring about a concomitant deterioration in crystal quality [46].

\subsection{Effects of pressure on the three-membered linear metal chain $\left[\mathrm{Co}_{3}\left(2,2^{\prime} \text { '-dipyridylamide }\right)_{4}\right.$ - $\left.\mathrm{Cl}_{2}\right] \cdot \mathrm{CH}_{2} \mathrm{Cl}_{2}$}

Using a combination of synchrotron and laboratory sources, the Iversen group undertook the study of the symmetrical three-membered linear metal chain $\left[\mathrm{Co}_{3}(\mathrm{dpa})_{4} \mathrm{Cl}_{2}\right] \cdot \mathrm{CH}_{2} \mathrm{Cl}_{2}\left(\mathrm{dpa}^{-}=2,2^{\prime}\right.$-dipyridylamide anion $)$ to $3.2 \mathrm{GPa}$ (Figure 26) [47]. Synchrotron data were collected at the Advanced Photon Source at Argonne National Laboratory, USA, and used to obtain an equation of state, giving a bulk modulus of $c a .5 \mathrm{GPa}$ between ambient pressure and $2.58 \mathrm{GPa}$. Using Mo $K \alpha$ radiation, single crystal structural data were obtained using laboratory Agilent SuperNova and Bruker SMART APEX instruments. At ambient temperature and pressure, the dichloromethane solvent is disordered over two sites, designated $\mathbf{A}$ and $\mathbf{B}$, with the $\mathbf{A}$ site being more highly populated, and the application of pressure causes the occupancy of these sites to become more equivalent. This is rationalised by Hirshfeld fingerprint plot analysis which shows that occupation of the $\mathbf{B}$ site at both ambient pressure and $0.74 \mathrm{GPa}$ gives rise to very short $\mathrm{H} \cdots \mathrm{H}$ contacts with the coordination complex that are not present for the $\mathbf{A}$ site. However, the application of further pressure causes similar highly-repulsive interactions to be generated at the $\mathbf{A}$ site and, with the energy difference between the sites diminished, their occupancies equalise. The investigation also found that between ambient pressure and 0.32 GPa there is an apparent increase of 0.013(4) $\AA$ in the length of the terminal $\mathrm{Co}-\mathrm{Cl}$ bond, after which it contracts gradually as the pressure is raised to $3.2 \mathrm{GPa}$. The authors carried out numerous data collections between ambient pressure and $0.5 \mathrm{GPa}$ to ascertain the reliability of this elongation and found it to be reproducible. An explanation for the phenomenon was sought via extensive computational calculations which suggest that a HOMO-SOMO or HOMO-LUMO thermally-driven excitation would result in higher 
electron density in $\mathrm{Co}-\mathrm{Cl}$ non-bonding or anti-bonding orbitals, respectively. The authors were unable to find any causative factor for this elongation in any other geometrical effect of pressure.

\section{Complexes Exhibiting Negative Linear Compressibility}

Negative linear compressibility (NLC) is the phenomenon whereby pressure causes a system to increase in length along one or more directions while undergoing an overall decrease in volume [48]. One mechanism for NLC involves a 'wine-rack' motif (Figure 27) where compression causes changes in the angles about pivot points which connect paths throughout the crystal but are themselves relatively static. Suggested applications for NLC compounds include as sensors, actuators, artificial muscles and as components of advanced structural materials.

\subsection{Large negative linear compressibility in $\left[\left(\mathrm{C}_{6} \mathbf{F}_{5} \mathrm{Au}\right)_{2}(\mu\right.$-1,4-diisocyanobenzene $\left.)\right], \mathrm{Zn}\left[\mathrm{Au}(\mathrm{CN})_{2}\right]_{2}$, $\operatorname{Ag}_{3}\left[\operatorname{Co}(\mathrm{CN})_{6}\right]$ and $\mathrm{KMn}\left[\operatorname{Ag}(\mathrm{CN})_{2}\right]_{3}$}

One system that gives rise to negative linear compressibility (NLC) is the linear organoauric complex $\left[\left(\mathrm{C}_{6} \mathrm{~F}_{5} \mathrm{Au}\right)_{2}(\mu\right.$-1,4-diisocyanobenzene) $]$ (Figure 28$)$, which does so despite there being no formal bond about the "hinge" (Figure 29), the complex crystallising as alternating sheets that give rise to a 'wine rack' motif when viewed down the $c$ axis [49]. Upon the application of pressure the angle about the pivot, measured as the torsion angle $\mathrm{NC}-\mathrm{Au} \cdots \mathrm{Au}-\mathrm{CN}$, closes from $74.314(9)$ to $63.87(18)^{\circ}$ up to $2.42 \mathrm{GPa}$, at which pressure a maximum in the length of the $a$ axis is observed. In this pressure range a negative linear compressibility of $-12.57 \mathrm{TPa}^{-1}$ is thus observed. The largest NLC value reported $\left[-42(5) \mathrm{TPa}^{-1}\right.$ between ambient pressure and $1.8 \mathrm{GPa}$ ] was found for the metal cyanate framework $\mathrm{Zn}\left[\mathrm{Au}(\mathrm{CN})_{2}\right]_{2}[50]$. Beyond $1.8 \mathrm{GPa}$ it undergoes a phase transition via loss of symmetry, at which point the NLC decreases greatly to $-6(3) \mathrm{TPa}^{-1}$ up to 14.2 GPa. Within the structure, helices interact via aurophilic interactions and as pressure is applied they are compressed at the sides causing them to lengthen as the $\mathrm{Au} \cdots \mathrm{Au}$ interactions are less compressible. As these helices lie parallel to the $a$ axis, it is the $a$ axis that experiences the observed NLC. Two other systems that have been studied are $\mathrm{Ag}_{3}\left[\mathrm{Co}(\mathrm{CN})_{6}\right]$ [51] and $\mathrm{KMn}\left[\mathrm{Ag}(\mathrm{CN})_{2}\right]_{3}$ [52], both of which exhibit NLC as a result of packing in a 'wine rack' framework. In $\mathrm{KMn}\left[\operatorname{Ag}(\mathrm{CN})_{2}\right]_{3}$, the extent of the NLC observed is comparable to that of $\left[\left(\mathrm{C}_{6} \mathrm{~F}_{5} \mathrm{Au}\right)_{2}(\mu-1,4\right.$-diisocyanobenzene $\left.)\right]$ at $-12.0(8) \mathrm{TPa}^{-1}$, while for $\mathrm{Ag}_{3}\left[\mathrm{Co}(\mathrm{CN})_{6}\right]$ the results were somewhat more striking with NLC of $-76(9) \mathrm{TPa}^{-1}$, but this only occurs over a narrow range between ambient pressure to $0.19 \mathrm{GPa}$. Furthermore, above this pressure $\mathrm{Ag}_{3}\left[\mathrm{Co}(\mathrm{CN})_{6}\right]$ undergoes a phase transition but continues to exhibit an NLC of $-5.3(3) \mathrm{TPa}^{-1}$.

\section{Spin-crossover Complexes}

Spin-crossover is a phenomenon that occurs for certain transition metal complexes whereby an external stimulus (e.g., a change in temperature or pressure, irradiation with light or the application of a magnetic field) alters the spin state between high-spin and low-spin. Because high-spin states occupy greater volumes than their low-spin counterparts, the application of pressure will tend to favour the latter and in favourable cases bring about a transition from a high-spin to a low-spin complex. The inherent bistability of the two spin 
states and the associated changes in physical properties such as colour or magnetism has led to proposed applications as switches, data storage devices and optical displays.

\subsection{Negative linear compression and spin-crossover in [Fe(dipyrido[3,2- $a: 2$ ',3'c]phenazine $\left.)_{2}(\mathrm{NCS})_{2}\right] \cdot$ pyridine}

The complex $\left[\mathrm{Fe}\left(\right.\right.$ dipyrido[3,2-a:2',3'-c]phenazine) $\left.{ }_{2}(\mathrm{NCS})_{2}\right] \cdot$ pyridine (Figure 30) shows a spin-crossover transition with a hysteresis of $40 \mathrm{~K}\left(T_{\mathrm{c}}^{\mathrm{HS}} \downarrow_{\mathrm{LS}}=123\right.$ and $\left.T_{\mathrm{cLS}} \uparrow^{\mathrm{HS}}=163 \mathrm{~K}\right)$ [53]. Under variable pressure and analysed by Raman spectroscopy, this conversion has not begun by $1.82 \mathrm{GPa}$, but becomes gradually observable at $2.48 \mathrm{GPa}$ and is complete by $2.87 \mathrm{GPa}$ [54]. High pressure X-ray diffraction has been used to follow the gradual effects of pressure on this transition and shows distinct non-linear compression of the $a$ axis resulting from a scissor-like opening effect in the molecule (Figure 31). This causes the angle between the planes of the two dipyrido[3,2-a:2',3'-c]phenazine ligands to increase further from $90^{\circ}$ owing to intercalation between neighbouring molecules. Counter to this, the spin-crossover transition would bring about a closing towards $90^{\circ}$ and is in accordance with the observation that low-spin coordination spheres adopt more idealised octahedral geometries than the corresponding high-spin ones. It was proposed that this acts as the source of inhibition of the spin-crossover transition under pressure.

\subsection{Two Fe(II) spin-crossover complexes: $\left[\mathrm{Fe}(1,10 \text {-phenanthroline })_{2}(\mathrm{NCS})_{2}\right]$ and $[\mathrm{Fe}(2,2$ '-bi-4,5- dihydrothiazine $\left.)_{2}(\mathrm{NCS})_{2}\right]$}

A high pressure crystallographic study of [Fe(1,10-phenanthroline $\left.)_{2}(\mathrm{NCS})_{2}\right]$ (Figure 32) and [Fe(2,2'-bi-4,5dihydrothiazine $)_{2}(\mathrm{NCS})_{2}$ ] (Figure 33) was the first reported for a spin-crossover complex. This study gave detailed structural information for these complexes at pressures of 1.0 and $0.95 \mathrm{GPa}$, respectively, obtained on an in-house STOE diffractometer using Mo Ka radiation [55]. A comparison of the data was made against structural data obtained at $130 \mathrm{~K}$, at which temperature it was known that the spin transition from high-spin to low-spin occurs. By analysis of the coordination sphere, within which the $\mathrm{Fe}-\mathrm{N}$ bonds of $[\mathrm{Fe}(1,10-$ phenanthroline $\left.)_{2}(\mathrm{NCS})_{2}\right]$ and $\left[\mathrm{Fe}\left(2,2^{\prime} \text {-bi-4,5-dihydrothiazine }\right)_{2}(\mathrm{NCS})_{2}\right]$ contract by 0.22 and $0.20 \AA$, respectively, at both high pressure and low temperature, it was possible to conclude, linked to spectroscopic evidence [56-59], that the high pressure structures were in the low-spin state. The transition point was then obtained by plotting unit cell dimensions obtained at numerous pressures and this point was identified in $\left[\mathrm{Fe}(1,10-\text { phenanthroline })_{2}(\mathrm{NCS})_{2}\right]$ by a sudden contraction in the $a$ axis around $0.6 \mathrm{GPa}$. For [Fe(2,2'-bi-4,5dihydrothiazine $)_{2}(\mathrm{NCS})_{2}$ ] the transition appeared far more subtle, in line with the temperature-dependent behaviour of this complex, but the authors used unit cell data to locate the transition at ca. 0.4 GPa.

\subsection{The structure of $\left[\mathrm{Fe}(\mathrm{N} \text {-2'-pyridylmethylene-4-aminoterphenyl })_{2}(\mathrm{NCS})_{2}\right]$ to $0.4 \mathrm{GPa}$}

Along with a number of similar complexes studied by temperature-dependent X-ray diffraction, Guionneau et al. studied the effects of pressure on the structure of [ $\mathrm{Fe}(\mathrm{N}-2$ '- pyridylmethylene-4aminoterphenyl $)_{2}(\mathrm{NCS})_{2}$ ] (Figure 34) to $0.4 \mathrm{GPa}$ [60]. The system is known to exhibit a gradual spincrossover transition from high-spin to low-spin with decreasing temperature, but this is not complete at $11 \mathrm{~K}$. 
The transition is associated (as above) with a decrease in $\mathrm{Fe}-\mathrm{N}$ bond lengths of $0.11-0.20 \AA$. The corresponding changes between ambient pressure and 0.4 GPa lie between -0.02 and $+0.03 \AA$, small compared to that expected for a spin-crossover transition, and the observed effects on coordination bond angles are similarly small. Despite this, the contraction in the unit cell volume due to pressure is comparable to cooling from 295 to $11 \mathrm{~K}$, although the changes to individual axes differ. This was attributed to the conditions inside the DAC applying (isotropic) hydrostatic pressure, whereas cooling with an open-flow cryostat allows the crystal to contract according to potentially anisotropic packing forces.

\subsection{Absence of spin-crossover transition with pressure in the complex [Mn(III)(pyrol) $)_{3}$ tren]}

The complex $\left[\mathrm{Mn}(\mathrm{III})(\mathrm{pyrol})_{3} \text { tren], where (pyrol) }\right)_{3}$ tren is a Schiff base of pyrrole-2-carboxaldehyde and triaminotriethylamine (Figure 35), exhibits a sudden spin-crossover transition from high-spin to low-spin over the range 45-35 $\mathrm{K}$ evidenced by a rapid decrease in the unit cell parameters of the cubic system [61]. This temperature-dependent phenomenon is associated with a contraction of $c a .0 .10 \AA$ in the lengths of the $\mathrm{Mn}-\mathrm{N}$ bonds. No spin-crossover transition is observed when pressure is applied, which may be surprising given that the contraction in unit cell volume between ambient pressure and $1.0 \mathrm{GPa}\left(599 \AA^{3}\right)$ is significantly greater than that found for the temperature-dependent transition (222 and $394 \AA^{3}$ at 44 and $30 \mathrm{~K}$, respectively). Furthermore, the number and proximity of intermolecular close contacts is similar between the high-pressure and low-spin structures. These factors led to the conclusion that the stress of pressurisation on the coordination sphere is not the defining factor that brings about the spin-crossover transition.

\subsection{A pressure-induced two-step spin transition in [ $\mathrm{Fe}\left(6,6^{\prime}\right.$-bis(amino-2-pyridyl)-2,2'- bipyridine)(NCS $\left.)_{2}\right]$}

A comprehensive study [62] on [Fe(6,6'-bis(amino-2-pyridyl)-2,2'-bipyridine)(NCS $)_{2}$ ] (Figure 36) using laboratory and synchrotron X-ray sources between ambient pressure and $0.97 \mathrm{GPa}$, coupled to magnetometry and Raman spectroscopy and obtaining pressure $v s$. temperature unit cell data has allowed collection of a large number of data points with which to build a phase diagram. Consistent with its temperature-dependent behaviour [63], pressurisation of the complex was found to undergo a two-step spin transition via an ordered 1:2 high-spin/low-spin intermediate phase. The first (high-spin to intermediate phase) transition at $c a .0 .45$ GPa involves a tripling of the $c$ axis with retention of crystal symmetry, giving supercell reflections for the intermediate phase. The intermediate phase to low-spin transition at $c a .1 .05 \mathrm{GPa}$ involves a loss of symmetry and conversion to space group $C$-1, a non-standard centred setting of $P-1$. Structural refinement of the triclinic phase was not possible owing to twinning that could not be resolved, in part owing to the limitations on the data collected from crystals held inside a DAC. Nevertheless, the transition was monitored by following the volume of the $\mathrm{Fe}$ coordination sphere, based on the observation that the $\mathrm{FeN}_{6}$ octahedron encloses a volume that is $c a .25 \%$ smaller for a low-spin complex than for its high-spin counterpart. The structural highlights of the high-spin and intermediate phases show the expected decrease in $\mathrm{M}-\mathrm{L}$ bond lengths for the spin-crossover transition and appear in the Supplementary Information of the article. 


\subsection{Gradual spin-crossover transitions in $\left[\left\{\mathrm{Fe}(2,6-b i s(\text { pyrazol-3-yl }) \text { pyridine })(\mathrm{NCS})_{2}\right\}_{2}\left(4,4^{\prime}-\right.\right.$ bipyridine)]·2MeOH}

Both the temperature-dependent and pressure-dependent spin-crossover transitions observed for the [\{Fe(2,6-bis(pyrazol-3-yl)pyridine)(NCS $\left.)_{2}\right\}_{2}(4,4$ '-bipyridine) $] \cdot 2 \mathrm{MeOH}$ (Figure 37) are found to be gradual, occurring over the ranges $120-80 \mathrm{~K}$ and $0.7-2.5 \mathrm{GPa}$, respectively [64]. In the temperature-dependent behaviour, the transition is found to be incomplete at $30 \mathrm{~K}$, halting at $50 \%$ conversion with one $\mathrm{Fe}(\mathrm{II})$ centre of each molecule in the high-spin state and the other in the low-spin state. This end-point is not found for the pressure-induced transition, which eventually results in a full low-spin system. Upon cooling there is a breaking of crystallographic symmetry resulting from an increase in the torsion angle involving the bridging 4,4'-bipyridine ligand. In a separate study [65], DFT calculations were used to argue that the increased twist disrupts the communication between the metal centres. Thus, cooling has the effect of limiting the degree of spin-crossover. The application of pressure, in contrast, does not involve such a structural transition, and this difference permits the complete transition, albeit gradually. The transition was monitored using structural parameters (M-L bond lengths) derived from data collected on Beamline I15 at Diamond Light Source. The decreases in unit cell dimensions, usually diagnostic of a spin-crossover transition in a variable-temperature study, are obscured by major compression of these dimensions as a direct consequence of pressure. The mean $\mathrm{Fe}-\mathrm{N}$ bond length of c.a. $2.16 \AA$ is essentially unaffected by pressures of up to $0.6 \mathrm{GPa}$, but thereafter undergoes a gradual contraction up to the maximum pressure studied structurally (1.6 GPa), where the mean $\mathrm{Fe}-\mathrm{N}$ bond length is 1.98(2) A. The Raman spectroscopic data reported in this study are consistent with a gradual spin-crossover transition commencing above $0.6 \mathrm{GPa}$.

\subsection{Neutron powder diffraction studies on [ $\left.\mathrm{Fe}\left(\mathrm{N}-2^{\prime} \text { '-pyridylmethylene-4-(phenylazo)-aniline }\right)_{2}(\mathrm{NCS})_{2}\right]$ and $\left[\mathrm{Fe}(N-2 \text { '-pyridylmethylene-4-aminobiphenyl })_{2}(\mathrm{NCS})_{2}\right]$}

Legrand et al. published a study [66] of the complexes [Fe( $N-2$ '-pyridylmethylene-4(phenylazo)aniline $\left.)_{2}(\mathrm{NCS})_{2}\right]$ (Figure 38) and $\left[\mathrm{Fe}(\mathrm{N} \text {-2'-pyridylmethylene-4-aminobiphenyl })_{2}(\mathrm{NCS})_{2}\right]$ (Figure 39) using data taken on the neutron powder diffractometer D2B at ILL, Grenoble. These complexes are known to vary greatly in their response to pressure [67]. [Fe( $N-2$ '-pyridylmethylene-4(phenylazo)aniline $)_{2}(\mathrm{NCS})_{2}$ ] shows a gradual increase in $T_{1 / 2}$ for spin-crossover with increasing pressure, whereas $\left[\mathrm{Fe}\left(\mathrm{N}-2^{2} \text { '-pyridylmethylene-4-aminobiphenyl }\right)_{2}(\mathrm{NCS})_{2}\right]$, for which there are two known polymorphs, behaves somewhat differently. For one polymorph, denoted $\mathbf{p I}$, which at ambient pressure gives a complete and abrupt spin-crossover transition with a very small hysteresis of $5 \mathrm{~K}$, exhibits the normal stabilisation of the low-spin state with pressure up to $0.6 \mathrm{GPa}$, after which an increase of pressure to $0.8 \mathrm{GPa}$ causes a strong increase in hysteresis to $25 \mathrm{~K}$, which then drops again after $0.8 \mathrm{GPa}$. The high pressure spin-crossover behaviour of the other polymorph, pII, had not been reported at the time of this publication. This variety of behaviour made these complexes prime candidates for a structural study which was carried out using neutron powder diffraction to $1.1 \mathrm{GPa}$ in both cases. Only unit cell parameters are reported, but the behaviour of these corroborate the transition point previously described for [ $\mathrm{Fe}\left(\mathrm{N}-2^{\prime}\right.$-pyridylmethylene-4-

(phenylazo)aniline $\left.)_{2}(\mathrm{NCS})_{2}\right]$. Phase $\mathbf{p I}$ of $\left[\mathrm{Fe}\left(\mathrm{N}-2^{\prime} \text {-pyridylmethylene-4-aminobiphenyl }\right)_{2}(\mathrm{NCS})_{2}\right]$ was studied 
and found to remain in the high-spin state across the pressure range, transforming to pII at $0.75 \mathrm{GPa}$ in a phase transition from Pccn to $\mathrm{P} 2{ }_{1} / c$. The authors associate the phase transition with a $40 \%$ increase in the length of the $a$ axis, a $15 \%$ decrease in $b$ and little change in $c$. The net effect is to increase the cell volume by $c a .8 \%$ from its value at ambient pressure. This transition corresponds well with the unusual pressuredependent behaviour found for $\mathbf{p I}$ and is, therefore, proposed as its source.

\section{Molecular Magnetic Materials}

Single-molecule magnets (SMMs) are molecules that can be magnetised by a magnetic field, remaining so after the inducing field is removed. Crucially, this is a property of the actual molecule which does not depend on interactions with other structural units, in contrast to traditional magnets. Single-molecule magnetism is therefore not restricted to the solid state, and SMMs can be dispersed without losing their properties. Potential applications proposed for SMMs include high-density information storage and quantum computing. The archetype of single-molecule magnets is $\left[\mathrm{Mn}_{12} \mathrm{O}_{12}(\mathrm{OAc})_{16}\left(\mathrm{H}_{2} \mathrm{O}\right)_{4}\right][68,69]$, and high-pressure studies have focused on such Mn-based systems.

\subsection{High-pressure structural and magnetic studies on two $[\mathrm{Mn}]_{6}$ clusters}

Building on their earlier communication [70], Prescimone et al. reported the first combined high-pressure study [71] comparing single crystal diffraction and magnetism on two $[\mathrm{Mn}]_{6}$ clusters $\left[\mathrm{Mn}_{6} \mathrm{O}_{2}(2-\right.$ hydroxyphenylpropanone $\left.)_{6}(\mathrm{~L})_{2}(\mathrm{EtOH})_{6}\right]\left(\mathrm{L}=\mathrm{O}_{2} \mathrm{CPh}(\mathrm{Me})_{2}\right.$ or naphthalene carboxylate; Figure 40). Such an approach offers a unique method of studying the effect of structural factors on the magnetic properties of SMMs. The alternative is to use different bridging ligands, which affects several variables at once. This study, carried out at the Daresbury SRS, investigated the effect of pressure up to $1.5 \mathrm{GPa}$, and the subtle structural effects it brings about that in turn affect the magnetic behaviour of two $\mathrm{Mn}_{6}$ clusters. The molecules in question contain a centre of inversion, giving half a cluster per asymmetric unit, so the discussion is therefore with reference to half of the hexametallic unit.

It has been previously reported [72-76] that torsion angles of greater than $\mathrm{ca} .31^{\circ}$ on a two-atom bridge between metal centres gives rise to ferromagnetic exchange, whereas those less than $\mathrm{ca} .31^{\circ}$ give antiferromagnetic exchange. The application of pressure causes a flattening of the $\mathrm{Mn}-\mathrm{N}-\mathrm{O}-\mathrm{Mn}$ torsion angles in $\left[\mathrm{Mn}_{6} \mathrm{O}_{2}(2 \text {-hydroxyphenylpropanone })_{6}(\mathrm{~L})_{2}(\mathrm{EtOH})_{6}\right]$, causing one such angle in each system to fall below $31^{\circ}$. The magnetic behaviour above $1.1 \mathrm{GPa}$ could subsequently only be modelled with the switch of one interaction from ferromagnetic to anti-ferromagnetic exchange, corroborating previous reports. Other structural effects of pressure are to bring anisotropic compression to the $\mathrm{Mn}-\mathrm{O}$ bonds by $0.075(6) \AA$ for $\mathrm{L}=$ $\mathrm{O}_{2} \mathrm{CPh}(\mathrm{Me})_{2}$ and 0.081(8) $\AA$ for $\mathrm{L}=$ naphthalene carboxylate along the Jahn-Teller axes, defined as the bond axes perpendicular to the plane of the trimetallic core. In addition to the switching of one pairwise exchange per asymmetric unit, the effect on the magnetic properties of the whole molecule is to weaken exchange and decrease the energy of excited states.

\subsection{High pressure effects on a trimetallic $\mathrm{Mn}(\mathrm{II}) / \mathrm{Mn}(\mathrm{III})$ single-molecule magnet}


The trimetallic single-molecule magnet $\left[\mathrm{Mn}_{3}(\text { cis }, \text { cis-1,3,5-cyclohexanetriol })_{2}\left(2,2^{\prime}\right.\right.$ -

bipyridine) $\left.)_{4}\right]\left(\mathrm{ClO}_{4}\right)_{3} \cdot \mathrm{Et}_{2} \mathrm{O} \cdot 2 \mathrm{MeCN}$ (Figure 41 ), comprising one $\mathrm{Mn}$ (III) and two $\mathrm{Mn}$ (II) centres was studied under pressure using $0.4767 \AA$ radiation at the SRS [77]. The application of pressure resulted in expulsion of the solvent of crystallisation at $0.16 \mathrm{GPa}$ before going on to compress the equatorial $\mathrm{Mn}(\mathrm{III})-\mathrm{O}$ bonds. This serves to decrease the $\mathrm{Mn}(\mathrm{III}) \cdots \mathrm{Mn}$ (II) separation, although no change in the $\mathrm{Mn}$ (II) $-\mathrm{O}$ bond length was reported. As there is little or no change observed in the other structural parameters, such as deformation of angles across the bridging ligands that typically affect the magnetic properties in the Jahn-Teller axis or the equatorial plane, this structural modification is represented as the likely origin of the decrease in exchange energy and in the energy of excited states with pressure as it serves to gradually bring the metal centres closer together.

\subsection{Pressure-induced switching of the Jahn-Teller axis in $\left[\mathrm{Mn}_{12} \mathrm{O}_{12}\left(\mathrm{O}_{2} \mathrm{CCH}_{2}{ }^{\mathrm{t}} \mathrm{Bu}\right)_{16}\left(\mathrm{H}_{2} \mathrm{O}\right)_{4}\right] \mathrm{CH}_{2} \mathrm{Cl}_{2} \cdot \mathrm{MeNO}_{2}$}

In a combined study [78] comparing single crystal X-ray structures with magnetic properties, Parois et al. observed the pressure-induced switching of the Jahn-Teller axis at one of the metal centres in singlemolecule magnet complex $\left[\mathrm{Mn}_{12} \mathrm{O}_{12}\left(\mathrm{O}_{2} \mathrm{CCH}_{2}{ }^{\mathrm{t}} \mathrm{Bu}\right)_{16}\left(\mathrm{H}_{2} \mathrm{O}\right)_{4}\right] \mathrm{CH}_{2} \mathrm{Cl}_{2} \cdot \mathrm{MeNO}_{2}$ (Figure 42). Under ambient conditions, all except one of the $\mathrm{Mn}$ (III) Jahn-Teller axes are in approximate alignment, with one another out of the plane of the molecule; the remaining one (highlighted in green in Figure 42) is approximately perpendicular to these. It was also noted that there is no distinct Jahn-Teller axis at this Mn centre at ambient pressure as the $\mathrm{Mn}-\mathrm{O}$ bonds at the centre span the range 1.94(2)-2.082(15) $\mathrm{A}$ and do not adopt distinct equatorial and Jahn-Teller-elongated values. The bimodal distribution of $\mathrm{Mn}-\mathrm{O}$ distances at octahedral $\mathrm{Mn}$ centres in the CSD [6] suggests that these bond lengths for Jahn-Teller distorted systems typically tend to be ca. 1.9 for equatorial and $c a .2 .2 \AA$ the elongated axial bonds. As the pressure is increased, the two greatest components of strain are found to bring about compression in the plane of the molecule, about the misaligned Jahn-Teller axis, pushing it into alignment with the others. This behaviour is observed by tracking the $\mathrm{Mn}-\mathrm{O}$ bond distances. This is a gradual process involving disorder in the orientation of the Jahn-Teller axis up to and including a pressure of $1.5 \mathrm{GPa}$, only becoming notably fixed in the out-of-plane orientation with the others at $2.5 \mathrm{GPa}$. This magnetic behaviour is distinct from the rapid relaxation at ambient pressure, with a marked increase in the energy of the barrier to relaxation observed at $0.47 \mathrm{GPa}$. As pressure is increased, the proportion of fast-relaxing species decreases until, at $1.44 \mathrm{GPa}$, only slow-relaxing species remain. This marked but gradual change in magnetic behaviour is attributed to the alignment of the misaligned Jahn-Teller axis with the others with increasing pressure.

\subsection{A high-pressure structural study of two oxo-bridged $\mathrm{Mn}(\mathrm{III}) / \mathrm{Mn}(\mathrm{IV})$ complexes}

A synchrotron-based study was undertaken on the complexes $\left[\mathrm{Mn}_{2} \mathrm{O}_{2}\left(2,2^{\prime} \text {-bipyridine }\right)_{4}\right]\left(\mathrm{ClO}_{4}\right)_{3} \cdot 3 \mathrm{CH}_{3} \mathrm{CN}$ and $\left[\mathrm{Mn}_{2} \mathrm{O}_{2}\left(2,2^{\prime} \text {-bipyridine }\right)_{4}\right]\left(\mathrm{PF}_{6}\right)_{3} \cdot 2 \mathrm{CH}_{3} \mathrm{CN} \cdot \mathrm{H}_{2} \mathrm{O}$ (Figure 43) at the Daresbury SRS, this time with $0.4863 \AA$ radiation [79] . For each system, there is little effect on the $<\mathrm{Mn}-\mathrm{O}-\mathrm{Mn}$ bridging angle with increasing pressure, but a decrease in the $\mathrm{Mn} \cdots \mathrm{Mn}$ separation attributed to a contraction of $c a .0 .01 \AA$ in length of the 
bridging $\mathrm{Mn}-\mathrm{O}$ bonds is observed, although high standard uncertainties are inherent in the refinement. At high pressure, the solvent in $\left[\mathrm{Mn}_{2} \mathrm{O}_{2}(2,2 \text { '-bipyridine })_{4}\right]\left(\mathrm{ClO}_{4}\right)_{3} \cdot 3 \mathrm{CH}_{3} \mathrm{CN}$ could be located and refined, but for [ $\left.\mathrm{Mn}_{2} \mathrm{O}_{2}(2,2 \text { '-bipyridine })_{4}\right]\left(\mathrm{PF}_{6}\right)_{3} \cdot 2 \mathrm{CH}_{3} \mathrm{CN} \cdot \mathrm{H}_{2} \mathrm{O}$ the SQUEEZE routine [44] of PLATON [45] was required to model the solvent. However, the electron count did not agree with what would ordinarily be predicted for a high pressure study, with pressure causing an increase in the void electron count rather than a decrease. Low data completeness inherent in a high-pressure experiment might prevent the SQUEEZE algorithm from functioning correctly and so produce anomalous results. However, given that all structures sample the same region of reciprocal space to the same completeness, the authors suggest that it would be more reasonable to attribute the increase in void electron count between 1.75 and $3.00 \mathrm{GPa}$ at least partly to the entry of molecules of the hydrostatic medium (petroleum ether) into the crystal. $\left[\mathrm{Mn}_{2} \mathrm{O}_{2}\left(2,2^{\prime}-\right.\right.$ bipyridine $\left.)_{4}\right]\left(\mathrm{ClO}_{4}\right)_{3} \cdot 3 \mathrm{CH}_{3} \mathrm{CN}$ and $\left[\mathrm{Mn}_{2} \mathrm{O}_{2}\left(2,2^{\prime} \text {-bipyridine }\right)_{4}\right]\left(\mathrm{PF}_{6}\right)_{3} \cdot 2 \mathrm{CH}_{3} \mathrm{CN} \cdot \mathrm{H}_{2} \mathrm{O}$ were investigated to 0.87 and $0.84 \mathrm{GPa}$, respectively, which confirmed that their magnetic properties were unaffected over this pressure range.

\subsection{Combined magnetic and structural studies of the antiferromagnet $\left[\left(\mathrm{CH}_{3}\right)_{4} \mathrm{~N}\right]\left[\mathrm{MnCl}_{3}\right]$}

A pressure study on the one-dimensional linear chain antiferromagnet $\left[\mathrm{NMe}_{4}\right]\left[\mathrm{MnCl}_{3}\right]$ (Figure 44) was taken to $1.7 \mathrm{GPa}$ [80], above which there appeared to be a transformation from a hexagonal to a monoclinic phase. This change is associated with a loss of crystal quality and therefore could not be confirmed fully. Increasing pressure has only gradual structural effects, compressing the chains along their axes by decreasing the $<\mathrm{Mn}-\mathrm{Cl}-\mathrm{Mn}$ and $<\mathrm{Cl}-\mathrm{Mn}-\mathrm{Cl}$ angles along the chain $\left[\Delta=-1.03(10)^{\circ}\right.$ and $-0.76(7)^{\circ}$ respectively $]$, and opening the $<\mathrm{Cl}-\mathrm{Mn}-\mathrm{Cl}$ angle at each individual $\mathrm{Mn}$ centre $\left[\Delta=0.76(7)^{\circ}\right]$. There is also a slight contraction of $0.035(13) \AA$ in the $\mathrm{Mn}-\mathrm{Cl}$ bond, bringing about a reduction in the $\mathrm{Mn} \cdots \mathrm{Mn}$ separation of $0.06 \AA$. The effect of this narrowing of the bridging angle and the consequent shortening of the $\mathrm{Mn} \cdots \mathrm{Mn}$ separation is to increase antiferromagnetic exchange in the system.

\subsection{A high pressure structural-magnetic study of the magnetic sponge \\ $\left\{\left[\mathrm{Mn}(\mathrm{III})(\text { pyridazine })\left(\mathrm{H}_{2} \mathrm{O}\right)_{2}\right]\left[\mathrm{Mn}(\mathrm{II})\left(\mathrm{H}_{2} \mathrm{O}\right)_{2}\right]\left[\mathrm{Nb}(\mathrm{IV})(\mathrm{CN})_{8}\right] \cdot 3 \mathrm{H}_{2} \mathrm{O}\right\}_{n}$}

High-pressure single-crystal X-ray diffraction and magnetic studies of the three-dimensional 'magnetic sponge' $\left\{\left[\mathrm{Mn}(\mathrm{II})(\text { pyridazine })\left(\mathrm{H}_{2} \mathrm{O}\right)_{2}\right]\left[\mathrm{Mn}(\mathrm{II})\left(\mathrm{H}_{2} \mathrm{O}\right)_{2}\right]\left[\mathrm{Nb}(\mathrm{IV})(\mathrm{CN})_{8}\right] \cdot 3 \mathrm{H}_{2} \mathrm{O}\right\}_{n}$ (Figure 45) were carried out [81]. The framework is based on a trimetallic unit comprising one $\mathrm{Nb}$ (IV) and two $\mathrm{Mn}$ (II) cations. The only statistically significant distortion resulting from the application of $1.8 \mathrm{GPa}$ pressure is to the orientation of the pyridazine ligand bound to the $\mathrm{Mn}$ (II) centre, the plane of which is tilted from its ambient position by $17.0(5)^{\circ}$ (Figure 46). Nevertheless, a compression of $7.6 \%$ in the unit cell volume is observed and the apparent local geometry of the coordination spheres of the metal centres is indeed compressed with the $\mathrm{Mn} \cdots \mathrm{Nb}$ separation decreasing by $0.10 \AA$. The effect of pressure on the magnetic properties of this system is to increase the critical temperature, indicating enhanced antiferromagnetic coupling between the $\mathrm{Mn}$ and $\mathrm{Nb}$ sub-lattices. This is attributed to the shortening of $\mathrm{Nb}^{-} \mathrm{C}$ bonds which increases the indirect interaction of the metal centres via the bridging cyano ligands. 


\section{Molecular Conducting Materials}

Molecular conducting materials, including those exhibiting spin-Peierls transitions [82], represent a significant part of the early literature on high pressure studies of molecular crystals. The predominant features of these studies are the contractions in the lengths of the intermolecular contacts which correlate with observed changes in physical properties. In contrast, only minor effects on the intramolecular geometries of the inorganic or organic components are observed in these studies.

\subsection{Pressure-induced transitions in the spin-Peierls compound $\alpha^{\prime}-(\mathrm{BEDT}-\mathrm{TTF})_{2} \mathrm{Ag}(\mathrm{CN})_{2}$ (BEDT-TTF $=$ bis(ethylenedithio)tetrathiafulvalene)}

The spin-Peierls complex $\alpha^{\prime}-(\mathrm{BEDT}-\mathrm{TTF})_{2} \mathrm{Ag}(\mathrm{CN})_{2}$ (BEDT-TTF = bis(ethylenedithio)tetrathiafulvalene; Figure 47) exhibits a semiconductor-semiconductor phase transition with variation of both pressure (at 0.8 $\mathrm{GPa}, 298 \mathrm{~K}$ ) and temperature ( $260 \mathrm{~K}$, ambient pressure). This is accompanied by a crystallographic phase transition that includes a doubling of the $b$ axis but no change in the space group [83]. The complex $\left[\mathrm{Ag}(\mathrm{CN})_{2}\right]$ does not undergo any geometric changes as an effect of applied pressure, and minor distortions are observed in the organic cation which appears to undergo a charge transfer and a slight distortion in packing. The greatest changes, as is common at such pressures (>1.1 GPa), are found in intermolecular distances and orientations involving the organic cations.

\subsection{Effects on the structure of the magnetic molecular conductor (BEDT-TTF) ${ }_{3} \mathrm{CuBr}_{4}$}

Previous studies on the magnetic molecular conductor (BEDT-TTF) ${ }_{3} \mathrm{CuBr}_{4}$ confirmed that the conductance of the complex is heavily dependent on pressure, increasing from semiconducting to metallic by $c a$. $0.5 \mathrm{GPa}$. High pressure diffraction studies on the complex at 0.45 and $1.0 \mathrm{GPa}$ and at ambient pressures and low temperature afforded structural insights into this transition [84]. Only marginal changes to the molecular geometry of the ions are observed on increasing pressure. However, intermolecular $\mathrm{S} \cdots \mathrm{S}$ contacts between the organic cations in neighbouring stacks decrease significantly by $c a .0 .13 \AA$ across the 1.0 GPa pressure range, consistent with the pressure-induced increase in conductance. A small amount of slippage of the cations over one another, $c a .0 .1 \AA$ along the long axis of the molecule away from overlap and $0.2 \AA$ along the short axis towards overlap, is also observed. The inorganic $\mathrm{CuBr}_{4}{ }^{3-}$ counteranion resides on an inversion centre and is unaffected by the applied pressure.

\subsection{Pressure-induced deformations in $\kappa-\left[(\mathrm{BEDT}-\mathrm{TTF})_{2} \mathrm{Cu}(\mathrm{NCS})_{2}\right]$, a superconducting charge-transfer salt}

Unlike in the previous two studies, a degree of pressure-induced deformation is clearly seen in the geometry of the inorganic $\left[\mathrm{Cu}(\mathrm{NCS})_{2}\right]^{-}$anion of the superconducting charge-transfer salt $\kappa-\left[(\mathrm{BEDT}-\mathrm{TTF})_{2} \mathrm{Cu}(\mathrm{NCS})_{2}\right]$ [85]. At ambient pressure one thiocyanate anion bridges two $\mathrm{Cu}(\mathrm{I})$ centres and the other binds terminally, but with its sulfur atom directed orthogonal to a neighbouring $\mathrm{NCS}^{-}$moiety (Figure 48). The salt was investigated to $0.75 \mathrm{GPa}$, and the bridging anion is largely unchanged by pressure, with $\mathrm{Cu}-\mathrm{N}$ contracting by 
$0.03 \AA$ and $\mathrm{Cu}-\mathrm{S}$ by $0.02 \AA$, but with little other deformation observed. In contrast, the terminal thiocyanate anion is subject to a number of pressure-induced deformations. Along with a similar $\mathrm{Cu}-\mathrm{N}$ contraction of $0.04 \AA$, the $\mathrm{C} \equiv \mathrm{N}$ bond length decreases from 1.17 to $1.12 \AA$ whilst the $\mathrm{C}-\mathrm{S}$ bond elongates from 1.61 to 1.72 $\AA$. This size of this increase exceeds the average decrease in the intermolecular S $\cdots S$ distances between the BEDT-TTF components of the crystal $(0.09 \AA)$. The overall effect on the coordination geometry around the $\mathrm{Cu}(\mathrm{I})$ centre is substantial, most noticeably in the $\mathrm{C}-\mathrm{N}-\mathrm{Cu}$ angle which narrows from 167 to $152^{\circ}$.

\subsection{High pressure studies of the molecular wires $\left[\mathrm{M}(\mathrm{dpg})_{2}\right]\left(\mathrm{M}=\mathrm{Ni}, \mathrm{Pt} ; \mathrm{dpg}^{-}=\right.$ diphenylglyoximate $)$ and $\left[\operatorname{Pt}(\mathrm{dmg})_{2}\right]\left(\mathrm{dmg}^{-}=\right.$dimethylglyoximate $)$}

Several studies have been carried out on the closely-related square planar $\mathrm{d}^{8} \mathrm{M}(\mathrm{II})$ complexes $\left[\mathrm{M}(\mathrm{dpg})_{2}\right](\mathrm{M}$ $=\mathrm{Ni}$ [22], Pt [86]; $\mathrm{dpg}^{-}=$diphenylglyoximate) and [ $\left.\mathrm{Pt}(\mathrm{dmg})_{2}\right]\left(\mathrm{dmg}^{-}=\right.$dimethylglyoximate) [87] (Figure 49), which pack in one-dimensional stacks. Interest in these arises from their known properties, including the strong pressure-dependency of their resistivity [88-92] and piezochromism [93-96]. The packing of such systems gives rise to what can be described as atomic wires running parallel to one crystallographic axis. These studies were carried out using synchrotron powder X-ray diffraction at the Photon Factory, Tsukuba, Japan $[22,86]$ or by single-crystal X-ray diffraction on a laboratory Rigaku diffractometer [87] and show the principal axis of compression coinciding with the direction of the $\mathrm{M} \cdots \mathrm{M}$ interactions. As there is no change in symmetry, these distances can be readily extrapolated from the data without the need for full structure determination and refinement, leading to the conclusion that the optical and electrical properties both appear to be closely related to the contraction induced in the $\mathrm{M} \cdots \mathrm{M}$ distances.

In 1989, Konno et al. performed single crystal high pressure X-ray diffraction experiments on [Pt(dmg $\left.)_{2}\right]$ [87] to give a full structure determination using a laboratory source, and discovering a pressure-induced proton transfer in the complex. Strong intramolecular hydrogen bonds between the oxime $\mathrm{O}$ atoms give rise to the formation of a macrocycle about the metal centre involving the two equatorially-bound ligands. In the ambient pressure structure, the $\mathrm{H}$ atoms involved in these interactions were found over a range of positions close to the atom designated as $\mathrm{O} 1$; however, at $2.39 \mathrm{GPa}$ (or by cooling to $150 \mathrm{~K}$ at ambient pressure) the $\mathrm{H}$ atoms become significantly more associated with atom $\mathrm{O} 2$, while $\mathrm{O} 1$ becomes more involved in intermolecular $\mathrm{O} \cdots \mathrm{H}-\mathrm{C}$ interactions with neighbouring methyl groups, which rotate by $60^{\circ}$ to allow these interactions to occur.

\subsection{Crystal structure of $\left[\left(\mathrm{C}_{2} \mathrm{H}_{5}\right)_{2}\left(\mathrm{CH}_{3}\right)_{2} \mathrm{~N}\right]\left[\mathrm{Pd}(\mathrm{dmit})_{2}\right]_{2}\left(\mathrm{dmit}^{2-}=1,3-\right.$ dithiole-2-thione-4,5 dithiolate)}

Using laboratory single crystal X-ray diffraction equipment equipped with Mo Ka radiation, Okano et al. have studied the molecular conductor $\left[\left(\mathrm{C}_{2} \mathrm{H}_{5}\right)_{2}\left(\mathrm{CH}_{3}\right)_{2} \mathrm{~N}\right]\left[\mathrm{Pd}(\mathrm{dmit})_{2}\right]_{2}[97]\left(\mathrm{dmit}^{2-}=1,3\right.$-dithiole-2-thione-4,5dithiolate; Figure 50) which exhibits superconductivity below $4 \mathrm{~K}$ at $0.24 \mathrm{GPa}$ [98]. This complex salt was known to undergo a transition to an insulator at $0.7 \mathrm{GPa}$ [99]. The high pressure X-ray diffraction analysis confirmed that by $0.8 \mathrm{GPa}$ the triclinic system had undergone a phase transition which involved a doubling of the $a$ parameter with retention of the $P-1$ space group. This was coupled with ordering of the organic 
cation, which was previously randomly disordered over two sites. Full structure determination at $1 \mathrm{GPa}$ showed asymmetric contraction in the packing of the organometallic component. At ambient pressure, the system packs into dimers stacked offset to each other along the $a$ axis with an intradimer Pd $\cdots P d$ distance of $3.161 \AA$ an intradimer separation of $3.339 \AA$ between the least squares planes of the molecules. At $1 \mathrm{GPa}$ these values contract to 3.101 and $3.290 \AA$, respectively, whereas the separation between the adjacent planes of two stacking dimers contracts from 3.750 to $3.557 \AA$ over the same pressure range with little intra- or interdimer slippage. Thus, the dimeric packing is retained to high pressure despite a differentiation in the system that gives rise to two crystallographically-inequivalent dimers in the stack. These results dispelled the previously-held belief that the transition in conductance properties was the result of a weakening of HOMOLUMO energy level inversion, a property characteristic of $\operatorname{Pd}(\mathrm{dmit})_{2}$ superconductors, as this reasoning is inconsistent with the retention of the dimeric structure.

\subsection{Effects of pressure on the intermolecular geometry of $\left[\mathrm{Au}(\mathrm{tmdt})_{2}\right]\left(\mathrm{tmdt}^{2-}=\right.$ trimethylenetetrathiafulvalenedithiolate), a molecular metal}

At the SPring-8 synchrotron in Japan, $0.4977 \AA$ radiation was used to investigate the effect of pressure on the structure of the single-component molecular metal $\left[\mathrm{Au}(\mathrm{tmdt})_{2}\right]\left(\mathrm{tmdt}^{2-}=\right.$ trimethylenetetrathiafulvalenedithiolate; Figure 51) [100]. Smooth contractions in all unit cell parameters indicate that there is no phase transition up to $10.7 \mathrm{GPa}$. At this pressure the unit cell volume was around $75 \%$ of the value at ambient pressure, suggesting that despite its metallic nature $\left[\mathrm{Au}(\mathrm{tmdt})_{2}\right]$ behaves as a typical molecular compound. High pressure has little observable effect on the covalent bonding network, but the $\mathrm{Au}-\mathrm{S}$ coordination bonds are on average shortened by 0.051(10) $\AA$. The effects of pressure in this system are most evident in the intermolecular distances, especially in the intermolecular S...S distances: even at ambient pressure these distances are short, spanning the range 3.45-3.71 $\AA$ between neighbouring co-planar molecules. A pressure of $0.2 \mathrm{GPa}$ is sufficient bring all of these contacts to less than the relevant van der Waals sum (3.70 $\AA$ ), and at $10.7 \mathrm{GPa}$ the closest of these is $2.729 \AA$, an overall decrease of ca. $0.6 \AA$. The close $\mathrm{S}^{\cdots} \mathrm{S}$ contacts are linked to the metallic nature of the crystal: the SOMO and SOMO-1 orbitals contain contributions located on approaching $\mathrm{S}$ atoms that protrude from the molecule in an in-plane manner and contribute greatly to the conduction band. The effect of pressure-induced contraction is therefore to increase both the orbital overlap and the conductivity of the system.

\section{Prospects for Future Research}

Synchrotron facilities will continue to offer uniquely powerful facilities for high pressure crystallographic studies: brighter incident beams and faster, more sensitive detectors represent two areas of development which will benefit this and other areas of research [101]. Because of the high degree of flexibility inherent in the geometry of metal coordination complexes, there is huge scope for inducing changes by the application of pressure. This flexibility takes various forms:

(a) Where alternative geometries exist, pressure may modify the geometry while conserving the coordination number: 
- four-coordinate complexes may be tetrahedral, square-planar or intermediate;

- five-coordinate complexes may be trigonal-bipyramidal, square-based pyramidal, intermediate or distorted;

- six-coordinate complexes are predominantly octahedral, possibly with tetragonal, rhombic or trigonal distortions, the latter leading to the relatively rare trigonal prismatic geometry;

- seven-coordinate limiting geometries are pentagonal-bipyramidal, monocapped octahedral and monocapped trigonal prismatic, with intermediate and distorted geometries possible;

- eight-coordinate geometries include square-antiprismatic and dodecahedral;

- nine-coordinate and higher geometries are found for some $f$-block complexes.

(b) Where the same metal centre exhibits a range of coordination numbers, these may be controlled using pressure:

For example, $\mathrm{Cu}$ (II) complexes may be five-coordinate or six-coordinate [6] and, as discussed in Section 2, the application of pressure may result in a change of coordination number. The general expectation is that the coordination number will increase with pressure, although there are cases where the opposite is observed [8, $10,36]$. The additional coordination may arise from enhanced intramolecular coordination, closer intermolecular contacts, or both. Possible consequences of the change in coordination number may be restricted to the individual metal centres, but may include dimerisation [32] or polymerisation $[9,13]$.

(c) Pressure may induce conformational changes, as in the rearrangement from a staggered to an eclipsed conformation in $\left[\mathrm{Co}_{2}(\mathrm{CO})_{6}\left(\mathrm{PPh}_{3}\right)_{2}\right]$ [27] or in the new [1233] conformation for the cyclic thioether ligand in $\left[\mathrm{PdCl}_{2}(1,4,7\right.$-trithiacyclononane)] [13].

(d) Minor systematic changes to intramolecular geometry, for example as seen in $\left[\mathrm{Co}\left(\mathrm{NH}_{3}\right)_{5} \mathrm{NO}_{2}\right] \mathrm{Cl}_{2}[40]$ are a common consequence of applying higher pressures, whereas the more striking deformation of $20^{\circ}$ at a ipso bridgehead carbon in $\left[\mathrm{Pd}(1,4,7\right.$-trithiacyclononane $\left.)\left(\mathrm{PPh}_{3}\right)_{2}\right]\left(\mathrm{PF}_{6}\right)_{2}[15]$ is unprecedented.

(e) A broad range of non-covalent interactions - such as the various flavours of hydrogen bonding, van der Waals, halogen bonding, $\pi \cdots \pi$, cation $\cdots \pi$, anion $\cdots \pi$, metal $\cdots$ metal and hydrophobic interactions - are potentially susceptible to manipulation by using pressure, providing ways to modify the form and degree of association within the structure. As noted in the many examples above, structural changes may be associated with variations to interesting physical properties such as colour, magnetism, conductivity or electronic structure. Structural transformations may also be accompanied by phase transitions.

\section{Concluding Remarks}

The application of pressure offers a particularly powerful way to investigate and manipulate chemical interactions and associated phenomena, and is an excellent technique to interrogate and understand the influence and nature of the many long-range supramolecular contacts that occur in advanced materials, 
catalysts, functional complexes and biology. It offers distinct advantages over methods such as chemical modification, largely by allowing geometric variables to be separated from chemical variables and so permitting far more systematic study. High pressure crystallography offers a unique and powerful tool for such investigations by allowing atomic-level resolution of the geometrical changes that occur as the pressure is varied. These changes can then be correlated with results from other high pressure techniques such as spectroscopy: although such techniques provide insight into various chemical and physical properties of a system, they do not always provide direct information on the underlying geometric changes, and so high pressure crystallography plays a special role in the study of intermolecular and intramolecular structural chemistry. The investigation of pressure dependence of structural features and parameters, and their correlation with the physical properties of coordination complexes such as UV/visible absorption, magnetism and conductivity, confirm that high-pressure X-ray crystallography is an excellent tool for probing such phenomena. The results obtained demonstrate the potential for applications of complexes, for example in optoelectronics, in devices such as sensors and in magnetic materials. Although the capabilities of laboratory $\mathrm{X}$-ray sources are continually improving, synchrotrons and other central facilities will continue to offer a range of advantages for high pressure studies on the diversity of metal coordination complexes.

\section{Acknowledgements}

We wish to express our thanks to Dr David R. Allan (Diamond Light Source, UK) for all his contributions to our very productive collaboration. We are grateful for the beamtime awarded at the Daresbury SRS and at Diamond Light Source. We thank the ERC and EPSRC for support.

\section{References}

[1] L. Merrill, Review of Scientific Instruments, 45 (1974) 290.

[2] S.A. Moggach, D.R. Allan, S. Parsons, J.E. Warren, J. Appl. Cryst., 41 (2008) 249.

[3] R.A. Forman, G.J. Piermani, J.D. Barnett, S. Block, Science, 176 (1972) 284.

[4] R.M. Hazen, T.C. Hoering, A.M. Hofmeister, J. Phys. Chem., 91 (1987) 5042.

[5] S.A. Moggach, S. Parsons, Spectroscopic Properties of Inorganic and Organometallic Compounds, 40 (2009) 324.

[6] F.H. Allen, Acta Crystallographica Section B: Structural Science, 58 (2002) 380.

[7] S.A. Moggach, Acta Crystallographica Section B: Structural Science, 70 (2014) in preparation.

[8] S.A. Moggach, K.W. Galloway, A.R. Lennie, P. Parois, N. Rowantree, E.K. Brechin, J.E. Warren, M. Murrie, S. Parsons, CrystEngComm, 11 (2009) 2601.

[9] K.W. Galloway, S.A. Moggach, P. Parois, A.R. Lennie, J.E. Warren, E.K. Brechin, R.D. Peacock, R. Valiente, J. González, F. Rodríguez, S. Parsons, M. Murrie, CrystEngComm, 12 (2010) 2516.

[10] A. Prescimone, J. Sanchez-Benitez, K.K. Kamenev, S.A. Moggach, J.E. Warren, A.R. Lennie, M. Murrie, S. Parsons, E.K. Brechin, Dalton Trans., 39 (2010) 113.

[11] J.A. Gould, M.J. Rosseinskya, S.A. Moggach, Dalton Trans., 41 (2012) 5464. 
[12] J.K. Clegg, M.J. Hayter, K.A. Jolliffe, L.F. Lindoy, J.C. McMurtrie, G.V. Meehan, S.M. Neville, S. Parsons, P.A. Tasker, P. Turner, F.J. White, Dalton Trans., 39 (2010) 2804.

[13] D.R. Allan, A.J. Blake, D. Huang, T.J. Prior, M. Schröder, Chemical Communications, (2006) 4081.

[14] D.R. Allan, D. Bailey, N. Bird, A.J. Blake, N.R. Champness, D. Huang, J. Keane, J. McMaster, T.J. Prior, J.P. Tidey, M. Schröder, Acta Crystallographica Section B: Structural Science, submitted.

[15] H.L.S. Wong, D.R. Allan, N.R. Champness, J. McMaster, M. Schröder, A.J. Blake, Angew. Chem. Int. Ed., 52 (2013) 5093.

[16] R.E. Dinnebier, S. van Smaalen, F. Olbrich, S. Carlson, Inorg. Chem., 44 (2005) 964.

[17] V.N. Sapunov, K. Kirchner, R. Schmid, Coordination Chemistry Reviews, 214 (2001) 143.

[18] M. Guido, G. Gigli, J. Chem. Phys., 65 (1976) 1397.

[19] D.M. Hassett, C.J. Marsden, Chemical Communications, (1990) 667.

[20] T.M. Timofeeva, J.H. Lii, N.L. Allinger, J. Am. Chem. Soc., 117 (1995) 7452.

[21] P.J. Byrne, P.J. Richardson, J. Chang, A.F. Kusmartseva, D.R. Allan, A.C. Jones, K.V. Kamenev, P.A. Tasker, S. Parsons, Chemistry - A European Journal, 18 (2012) 7738.

[22] K. Takeda, J. Hayashi, I. Shirotani, H. Fukuda, K. Yakushi, Mol. Cryst. Liq. Cryst., 460 (2006) 131.

[23] L.-C. Wu, J. Overgaard, S.R. Madsen, M.S. Schmoekel, B.B. Iversen, J. Ch. Chem. Soc., 60 (2013) 929.

[24] J.E. Schirber, B. Morosin, Physical Review Letters, 42 (1979) 1485.

[25] J.E. Schirber, B. Morosin, R.W. Alkire, A.C. Lawson, P.J. Vergarnini, Physical Review B: Condensed Matter, 29 (1984) 4150.

[26] N. Casati, P. Macchi, A. Sironi, Angew. Chem. Int. Ed., 44 (2005) 7736.

[27] N. Casati, P. Macchi, A. Sironi, Chemistry - A European Journal, 15 (2009) 4446.

[28] C. Slebodnick, J. Zhao, R.J. Angel, B.E. Hanson, Y. Song, Z. Liu, R.J. Hemley, Inorg. Chem., 43 (2004) 5245.

[29] S. Scheins, J. Overgaard, G.A. Timco, A. Stash, Y.-S. Chen, F.K. Larsen, M. Christensen, M.R.V. Jorgensen, S.R. Madsen, M.S. Schmokel, B.B. Iversen, Chemistry - A European Journal, 19 (2013) 195.

[30] C. Wilson, B.B. Iversen, J. Overgaard, F.K. Larsen, G. Wu, S.P. Palii, G.A. Timco, N.V. Gerbeleu, J. Am. Chem. Soc., 122 (2000) 11370.

[31] C. Hansson, S. Carlson, D. Giveen, M. Johansson, S. Yong, A. Oskarsson, Acta Crystallographica Section B: Structural Science, 62 (2006) 474.

[32] M. Bujak, R.J. Angel, J. Phys. Chem. B, 110 (2006) 10322.

[33] G.A. Fischer, N.C. Norman, Adv. Inorg. Chem., 41 (1994) 233.

[34] L. Sobczyk, R. Jakubas, J. Zaleski, Polish Journal of Chemistry, 71 (1997) 265.

[35] M. Bujak, J. Zaleski, J. Solid State Chem., 177 (2004) 3202.

[36] M. Bujak, R.J. Angel, J. Solid State Chem., 180 (2007) 3026.

[37] G.M. Espallargas, L. Brammer, D.R. Allan, C.R. Pulham, N. Robertson, J.E. Warren, J. Am. Chem. Soc., 130 (2008) 9058.

[38] E.V. Boldyreva, J. Kivikoski, J.A. Howard, Acta Crystallographica Section B: Structural Science, 53 (1997) 394. 
[39] E.V. Boldyreva, J. Kivikoski, J.A. Howard, Acta Crystallographica Section B: Structural Science, 53 (1997) 405.

[40] E.V. Boldyreva, Y.N. Naumov, H. Ahsbahs, Acta Crystallographica Section B: Structural Science, 54 (1998) 798.

[41] E.V. Boldyreva, Y.N. Naumov, H. Ahsbahs, Acta Crystallographica Section C: Crystal Structure Communications, 54 (1998) 1378.

[42] F.P.A. Fabbiani, G. Buth, B. Dittrich, H. Sowa, CrystEngComm, 12 (2010) 2541.

[43] C. Brink-Shoemaker, D.W.J. Cruickshank, D.C. Hodgkin, M.J. Kamper, Proc. R. Soc. London, Ser. A, 278 (1964) 1.

[44] P. van der sluis, A.L. Spek, Acta Crystallographica Section A: Foundations of Crystallography, 46 (1990) 194.

[45] A.L. Spek, Acta Crystallographica Section D: Biological Crystallography, 65 (2009) 148.

[46] F.P.A. Fabbiani, Personal communication.

[47] S. R. Madsen, M. K. Thomsen, S. Scheins, Y.-S. Chen, N. Finkelmeier, D. Stalke, J. Overgaard, B. B. Iversen, Dalton Trans., 43 (2014) 1313.

[48] R.H. Baughman, S. Stafström, C. Cui, S.O. Dantas, Science, 279 (1998) 1522.

[49] C.H. Woodall, C.M. Beavers, J. Christensen, L.E. Hatcher, M. Intissar, A. Parlett, S.J. Teat, C. Reber, P.R. Raithby, Angew. Chem. Int. Ed., 52 (2013) 9691.

[50] A.B. Cairns, J. Catafesta, C. Levelut, J. Rouquette, A. van der Lee, L. Peters, A.L. Thompson, V.

Dmitriev, J. Haines, A.L. Goodwin, Nature Materials, 12 (2013) 212.

[51] A.L. Goodwin, D.A. Keen, M.G. Tucker, Proc. Nat. Acad. Sci. USA, 105 (2008) 18708.

[52] A.B. Cairns, A.L. Thompson, M.G. Tucker, J. Haines, A.L. Goodwin, J. Am. Chem. Soc., 134 (2012) 4454.

[53] Z.J. Zhong, J.-Q. Tao, Z. Yu, C.-Y. Dun, Y.-J. Liu, J. You, Dalton Trans., (1998) 327.

[54] H.J. Shepherd, T. Palamarciuc, P. Rosa, P. Guionneau, G. Molnar, J.F. Letard, A. Bousseksou, Angew. Chem. Int. Ed., 51 (2012) 3910.

[55] T. Granier, B. Gallois, J. Gaultier, J.-A. Real, J. Zarembowitch, Inorg. Chem., 32 (1993) 5305.

[56] D.C. Fisher, H.G. Drickamer, J. Chem. Phys., 54 (1972) 4825.

[57] J.R. Ferraro, J. Takemoto, J. Appl. Spectrosc., 28 (1974) 66.

[58] D.M. Adams, G.J. Long, A.D. Williams, Inorg. Chem., 21 (1982) 149.

[59] J. Pebler, J. Inorg. Chem., 22 (1983) 4125.

[60] P. Guionneau, C. Brigouleix, Y. Barrans, A.E. Goeta, J.-F. Létard, J.A.K. Howard, J. Gaultier, D. Chasseau, Acad. Sci., Ser. IIc: Chim., 4 (2001) 161.

[61] P. Guionneau, M. Marchivie, Y. Garcia, J. Howard, D. Chasseau, Physical Review B: Condensed Matter, 72 (2005) 214408.

[62] H.J. Shepherd, S. Bonnet, P. Guionneau, S. Bedoui, G. Garbarino, W. Nicolazzi, A. Bousseksou, G. Molnár, Physical Review B: Condensed Matter, 84 (2011) 144107. 
[63] S. Bonnet, M.A. Siegler, J. Sánchez Costa, G. Molnár, A. Bousseksou, A.L. Spek, P. Gamez, J. Reedjik, Chemical Communications, (2008) 5619.

[64] H.J. Shepherd, P. Rosa, L. Vendier, N. Casati, J.F. Letard, A. Bousseksou, P. Guionneau, G. Molnar, Physical Chemistry Chemical Physics, 14 (2012) 5265.

[65] G.J. Halder, K.W. Chapman, S.M. Neville, B. Moubaraki, K.S. Murray, J.-F. Létard, C.J. Kepert, J. Am. Chem. Soc., 130 (2008) 17552.

[66] V. Legrand, F. Le Gac, P. Guionneau, J.-F. Létard, J. Appl. Cryst., 41 (2008) 637.

[67] V. Ksenofontov, G. Levchenko, H. Spiering, P. Gütlich, J.-F. Létard, Y. Bouhedja, O. Kahn, Chem. Phys. Lett., 294 (1998) 545.

[68] T. Lis, Acta Crystallographica Section B: Structural Science, 36 (1980) 2042.

[69] A. Caneschi, D. Gatteschi, R. Sessoli, A.L. Barra, L.C. Brunel, M. Guillot, J. Am. Chem. Soc., 113 (1991) 5873.

[70] A. Prescimone, C.J. Milios, S. Moggach, J.E. Warren, A.R. Lennie, J. Sanchez-Benitez, K. Kamenev, R. Bircher, M. Murrie, S. Parsons, E.K. Brechin, Angew. Chem. Int. Ed., 47 (2008) 2828.

[71] A. Prescimone, C.J. Milios, J. Sanchez-Benitez, K.V. Kamenev, C. Loose, J. Kortus, S. Moggach, M. Murrie, J.E. Warren, A.R. Lennie, S. Parsons, E.K. Brechin, Dalton Trans., (2009) 4858.

[72] C.J. Milios, R. Inglis, A. Vinslava, R. Bagai, W. Wernsdorfer, S. Parsons, S.P. Perlepes, G. Christou, E.K. Brechin, J. Am. Chem. Soc., 129 (2007) 12505.

[73] C.J. Milios, A. Vinslava, S.A. Moggach, S. Parsons, W. Wernsdorfer, G. Christou, S.P. Perlepes, E.K. Brechin, J. Am. Chem. Soc., 129 (2007) 2754.

[74] C.J. Milios, A. Vinslava, W. Wernsdorfer, A. Prescimone, P.A. Wood, S. Parsons, S.P. Perlepes, G. Christou, E.K. Brechin, J. Am. Chem. Soc., 129 (2007) 6547.

[75] C.J. Milios, A. Vinslava, P.A. Wood, S. Parsons, W. Wernsdorfer, G. Christou, S.P. Perlepes, E.K. Brechin, J. Am. Chem. Soc., 129 (2007) 8.

[76] C.J. Milios, S. Piligkos, E.K. Brechin, Dalton Trans., (2008) 1809.

[77] A. Prescimone, J. Sanchez-Benitez, K.V. Kamenev, S.A. Moggach, A.R. Lennie, J.E. Warren, M. Murrie, S. Parsons, E.K. Brechin, Dalton Trans., (2009) 7390.

[78] P. Parois, S.A. Moggach, J. Sanchez-Benitez, K.V. Kamenev, A.R. Lennie, J.E. Warren, E.K. Brechin, S. Parsons, M. Murrie, Chemical Communications, 46 (2010) 1881.

[79] A. Prescimone, J. Sanchez-Benitez, K.V. Kamenev, J.E. Warren, A.R. Lennie, M. Murrie, S. Parsons, E.K. Brechin, Zeitschrift Fur Naturforschung Section B, 65 (2010) 221.

[80] S. Tancharakorn, F.P.A. Fabbiani, D.R. Allan, K.V. Kamenev, N. Robertson, J. Am. Chem. Soc., 128 (2006) 9205.

[81] D. Pinkowicz, K. Kurpiewska, K. Lewiński, M. Bałanda, M. Mihalik, M. Zentková, B. Sieklucka, CrystEngComm, 14 (2012) 5224.

[82] J.W. Bray, L.V. Interrante, I.S. Jacobs, J.C. Bonner, Extended Linear Chain Compounds, Plenum, New York, 1993. 
[83] P. Guionneau, J. Gaultier, M. Rahal, G. Bravic, J.M. Mellado, D. Chasseau, L. Ducasse, M. Kurmoo, P. Day, J. Mater. Chem., 5 (1995) 1639.

[84] P. Guionneau, J. Gaultier, D. Chasseau, G. Bravic, Y. Barrans, L. Ducasse, D. Kanaawa, P. Day, M. Kurmoo, J. Phys. I France, 6 (1996) 1581.

[85] M. Rahal, D. Chasseau, J. Gaultier, L. Ducasse, M. Kurmoo, P. Day, Acta Crystallographica Section B: Structural Science, 53 (1997) 159.

[86] I. Shirotani, J. Hayashi, K. Takeda, Mol. Cryst. Liq. Cryst., 442 (2005) 157.

[87] M. Konno, T. Okamoto, I. Shirotani, Acta Crystallographica Section B: Structural Science, 45 (1989) 142.

[88] I. Shirotani, A. Kawamura, K. Suzuki, W. Utsumi, T. Yagi, Bull. Chem. Soc. Jpn., 64 (1991) 1607.

[89] I. Shirotani, A. Onodera, Y. Hara, J. Solid State Chem., 40 (1981) 180.

[90] K. Takeda, I. Shirotani, C. Seike, K. Yakushi, J. Phys. Condens. Matter., 12 (2000) L483.

[91] K. Takeda, I. Shirotani, K. Yakushi, Chem. Mater., 12 (2000) 912.

[92] K. Takeda, I. Shirotani, K. Yakushi, Synthetic Metals, 133-134 (2003) 415.

[93] Y. Ohishi, I. Hanazaki, S. Nagakura, Inorg. Chem., 9 (1970) 2551.

[94] K. Takacz, H.G. Drickamer, J. Chem. Phys., 85 (1986) 1184.

[95] I. Shirotani, K. Suzuki, T. Suzuki, T. Yagi, M. Tanaka, Bull. Chem. Soc. Jpn., 65 (1992) 1078.

[96] I. Shirotani, J. Hayashi, K. Takeda, Mol. Cryst. Liq. Cryst., 442 (2005) 145.

[97] Y. Okano, T. Adachi, B. Narymbetov, H. Kobayashi, B. Zhou, A. Kobayashi, Chem. Lett., 33 (2004) 938.

[98] H. Kobayashi, K. Bun, T. Naito, R. Kato, A. Kobayashi, Chem. Lett., (1990) 1909.

[99] A. Kobayashi, R. Kato, R.A. Clark, A.E. Underhill, A. Miyamato, K. Bun, T. Naito, H. Kobayashi, Synthetic Metals, 56 (1993) 297.

[100] Y. Okano, B. Zhou, H. Tanaka, T. Adachi, Y. Ohishi, M. Takata, S. Aoyagi, E. Nishibori, M. Sakata, A. Kobayashi, H. Kobayashi, J. Am. Chem. Soc., 131 (2009) 7169.

[101] D.R. Allan, A.J. Blake, M. Schröder, C. C. Tang, S. Yang, Phil. Trans. R. Soc. A, (2014) to be submitted. 


\section{Figure captions}

Figure 1. Schematic diagram of the $\left[\mathrm{Cu}_{2}(\mathrm{OH})(\mathrm{cit})(\mathrm{Gu})_{2}\right]^{-}\left(\mathrm{cit}^{4-}=\right.$ citrate; $\mathrm{Gu}=$ guanidine $)$ anion.

Figure 2. (a) View of the packing of $\left[\mathrm{Cu}_{2}(\mathrm{OH})(\mathrm{cit})(\mathrm{Gu})_{2}\right]^{-}\left(\mathrm{cit}^{4-}=\right.$ citrate; $\mathrm{Gu}=$ guanidine) anions at ambient pressure. The non-bonded interactions highlighted with dashed lines all contract under pressure to give the first high pressure phase via formation of intermolecular $\mathrm{C}-\mathrm{O} \cdots \mathrm{Cu}$ interactions. With further application of pressure across the second phase transition, half of these newly formed bonds break in alternate chains (b). This is coupled to a deviation of the bridging carboxylate in the binuclear complex towards the $\mathrm{Cu}$ (II) centre which no longer participates in the intermolecular $\mathrm{Cu}$ ' $\mathrm{O}$ interaction. For both figures, $\mathrm{Cu}$ atoms are in cyan, $\mathrm{N}$ in pale blue, $\mathrm{O}$ in red and $\mathrm{C}$ in grey, with $\mathrm{H}$ atoms and the $\mathrm{C}\left(\mathrm{NH}_{2}\right)_{2}$ groups of $\mathrm{Gu}$ ligands omitted for clarity.

Figure 3.Schematic diagram of the $\left[\mathrm{Cu}_{2}\left(\mathrm{cit}_{2}\right]^{4-}\left(\mathrm{cit}^{4-}=\right.\right.$ citrate $)$ anion.

Figure 4. Schematic diagram of (a) $\left[\mathrm{Cu}_{2}(\mathrm{OH})_{2}\left(\mathrm{H}_{2} \mathrm{O}\right)_{2}(\mathrm{tmen})_{2}\right]^{2+}$ (tmen = tetramethylethylenediamine); (b), $\left[\mathrm{Cu}_{2}(\mathrm{OH})_{2}(\text { tben })_{2}\right]^{2+}$ (tben = di- $t$-butylethylenediamine); and $(\mathrm{c})\left[\mathrm{Cu}_{2}(\mathrm{OH})_{2}(\mathrm{bpy})_{2}\right]\left(\mathrm{BF}_{4}\right)_{2}($ bpy $=2,2$ ' bipyridine).

Figure 5. View of the pressure induced change in the coordination of binuclear $\left[\mathrm{Cu}_{2}(\mathrm{OH})_{2}\left(\mathrm{H}_{2} \mathrm{O}\right)_{2}(\operatorname{tmen})_{2}\right]^{2+}$ (tmen $=$ tetramethylethylenediamine) viewed down the $\mathrm{O} \cdots \mathrm{O}$ vector of the bridging hydroxo groups (a) at ambient pressure and at $2.5 \mathrm{GPa}$ showing (b) complex $\mathbf{1}$ and (c) complex 2 of the triclinic phase. Note the location and relative distance of the nearest perchlorate oxygens over the metal centres at high pressure, linked by dashed lines. $\mathrm{Cu}$ atoms are in cyan, $\mathrm{Cl}$ in green, $\mathrm{N}$ in pale blue, $\mathrm{O}$ in red and $\mathrm{C}$ in grey, with $\mathrm{H}$ atoms omitted for clarity; perchlorate ions omitted in the ambient pressure phase (a).

Figure 6. Schematic diagram of $\left[\mathrm{Cu}^{\mathrm{II}}(L\right.$-aspartate $\left.)\left(\mathrm{H}_{2} \mathrm{O}\right)_{2}\right]$.

Figure 7. Schematic diagram of $\left[\mathrm{Cu}_{2}\left(\mu_{2}-1,1^{\prime}-(1,3-\text { phenylene }) \text { bis(4,4-dimethylpentane-1,3-dionato }\right)\right)_{2}(N$ methylmorpholine $)_{2}$ ].

Figure 8. Schematic diagram of $\left[\mathrm{PdCl}_{2}(1,4,7\right.$-trithiacyclononane)].

Figure 9. View of $\left[\mathrm{PdCl}_{2}(1,4,7\right.$-trithiacyclononane)] before (left, $4.25 \mathrm{GPa}$ ) and after (right, $4.6 \mathrm{GPa}$ ) the phase transition. Note the change in the conformation of the macrocycle, particularly in the aliphatic region at the top left of the Figure. $\mathrm{Pd}$ atoms are in blue, $\mathrm{S}$ in yellow, $\mathrm{C}$ in dark grey and $\mathrm{H}$ smaller in light grey. 
Figure 10. Schematic diagram of $\left[\mathrm{Pd}(1,4,7-\right.$ trithiacyclononane $\left.)\left(\mathrm{PPh}_{3}\right)_{2}\right]\left(\mathrm{PF}_{6}\right)_{2}$.

Figure 11. View of the four-fold phenyl embrace in $\left[\mathrm{Pd}(1,4,7\right.$-trithiacyclononane $\left.)\left(\mathrm{PPh}_{3}\right)_{2}\right]\left(\mathrm{PF}_{6}\right)_{2}$ at ambient pressure (left) and $6.55 \mathrm{GPa}$ (right). Note the greatly increased overlap of the $\pi$-stacked phenyl groups and the significant bending at their ipso carbons. $\mathrm{Pd}$ atoms are in blue, $\mathrm{P}$ in purple, $\mathrm{S}$ in yellow and $\mathrm{C}$ in grey with non-interacting phenyl moieties, macrocyclic carbons, hydrogen atoms and $\mathrm{PF}_{6}{ }^{-}$counteranions have been omitted for clarity.

Figure 12. Schematic diagram of $\mathrm{MCp}(\mathrm{M}=\mathrm{Li}, \mathrm{K}, \mathrm{Cs} ; \mathrm{Cp}=$ cyclopentadienyl $)$ polymer.

Figure 13. Schematic diagram of the common core of Ni(II) salicylaldoximato complexes.

Figure 14. Schematic diagram of $\left[\mathrm{Y}(\mathrm{DMF})_{4}\left(\mathrm{H}_{2} \mathrm{O}\right)_{3}(\mu-\mathrm{CN}) \mathrm{Fe}(\mathrm{CN})_{5}\right]$.

Figure 15. Schematic diagram of $[\mathrm{Co}(\mathrm{L})]\left(\mathrm{L}^{2-}=5,10,15,20\right.$-tetraphenyl-12H, 23H-porphinate)

Figure 16. Schematic diagram of $\left[\mathrm{Co}_{2}(\mathrm{CO})_{6}\left(\mathrm{XPh}_{3}\right)_{2}\right](\mathrm{X}=\mathrm{P}, \mathrm{As})$.

Figure 17. Schematic diagram of $\left[\mathrm{Ru}_{3}(\mathrm{CO})_{12}\right]$.

Figure 18. Schematic diagram of $\left[\mathrm{Fe}_{3} \mathrm{O}\left(\mathrm{O}_{2} \mathrm{CC}\left(\mathrm{CH}_{3}\right)_{3}\right)_{6}\right] \cdot\left(\mathrm{C}_{5} \mathrm{H}_{5} \mathrm{~N}\right)_{3}$.

Figure 19. Schematic diagram of $\left[\mathrm{PtCl}_{2}(\mathrm{dms})_{2}\right](\mathrm{dms}=$ dimethylsulfide $)$

Figure 20. Schematic diagram of the packing of $\left[\mathrm{SbCl}_{5}\right]^{2-}$ units in $\left[\left(\mathrm{CH}_{3}\right)_{2} \mathrm{NH}\left(\mathrm{CH}_{2}\right)_{2} \mathrm{NH}_{3}\right]\left[\mathrm{SbCl}_{5}\right]$. In the high pressure phase, the interaction highlighted with dashed lines changes to give alternating bonded and nonbonded interactions that give rise to dimers along the chain.

Figure 21. Schematic diagram of the packing of $\left[\mathrm{SbCl}_{5}\right]^{2-}$ units $\left[\left(\mathrm{CH}_{3}\right)_{2} \mathrm{NH}_{2}\right]_{2}\left[\mathrm{SbCl}_{5}\right]$ showing the formation of corner-sharing $\left[\mathrm{SbCl}_{6}\right]^{3-}$ octahedra.

Figure 22. Schematic diagram of the chain formation in (4-chloropyridinium) ${ }_{2}\left[\mathrm{CoX}_{4}\right](\mathrm{X}=\mathrm{Cl}, \mathrm{Br})$.

Figure 23. Schematic diagram of $\left[\mathrm{Co}\left(\mathrm{NH}_{3}\right)_{5} \mathrm{NO}_{2}\right]^{2+}$.

Figure 24. Schematic diagram of vitamin $B_{12}$. 
Figure 25. Diagram depicting the system of 'pockets' and 'channels' in the crystallographic packing of vitamin B12. The enclosed area represents one quarter of the unique $b c$ plane in orthorhombic space group $P 2_{1} 2_{1} 2_{1}$. The diagram is reproduced from J. P. Bouquiere, J. L. Finney, H. F. J. Savage, Acta Crystallogr. Sect. B: Structural Science, 50 (1994) 566 (http://dx.doi.org/10.1107/S0108768194002211) with permission of the International Union of Crystallography.

Figure 26. Image of $\left[\mathrm{Co}_{3}\left(2,2^{\prime} \text {-dipyridylamide }\right)_{4} \mathrm{Cl}_{2}\right]$. Co atoms in purple, $\mathrm{Cl}$ in green, $\mathrm{N}$ in blue and $\mathrm{C}$ in grey; Hydrogen atoms and dichloromethane solvate molecule omitted for clarity.

Figure 27. Diagram showing the deformation associated with a 'wine-rack' motif under hydrostatic pressure, with the central image representing the situation at ambient pressure. The image to the left illustrates the deformation that occurs when the interactions in the direction characterised by the wavy lines are less compressible than those characterised by the dashed lines, while the image to the right shows the opposite situation.

Figure 28. Schematic diagram of $\left[\left(\mathrm{C}_{6} \mathrm{~F}_{5} \mathrm{Au}\right)_{2}(\mu-1,4\right.$-diisocyanobenzene $\left.)\right]$.

Figure 29. Overlay view of neighbouring units of $\left[\mathrm{C}_{6} \mathrm{~F}_{5} \mathrm{Au}\right)_{2}(\mu$-1,4-diisocyanobenzene $\left.)\right]$ at ambient pressure (colour ball-and-stick diagram) and 4.39 GPa (monochrome stick diagram) depicting the opening of the system. Au atoms in yellow, $\mathrm{F}$ in green, $\mathrm{N}$ in blue and $\mathrm{C}$ in grey, with $\mathrm{H}$ atoms omitted for clarity.

Figure 30. Schematic diagram of $\left[\mathrm{Fe}\left(\text { dipyrido }\left[3,2-a: 2^{\prime}, 3^{\prime}-c\right] \text { phenazine }\right)_{2}(\mathrm{NCS})_{2}\right]$ - pyridine.

Figure 31.View of 'scissoring' mechanism that gives rise to negative linear compression.

Figure 32. Schematic diagram of $\left[\mathrm{Fe}(1,10-\text { phenanthroline })_{2}(\mathrm{NCS})_{2}\right]$.

Figure 33. Schematic diagram of [ $\left.\mathrm{Fe}(2,2 \text { '-bi-4,5-dihydrothiazine })_{2}(\mathrm{NCS})_{2}\right]$.

Figure 34. Schematic diagram of [Fe( $N-2^{\prime}$-pyridylmethylene-4-aminoterphenyl $\left.)_{2}(\mathrm{NCS})_{2}\right]$.

Figure 35. Schematic diagram of [Mn(III)(pyrol $)_{3}$ tren].

Figure 36. Schematic diagram of [Fe(6,6'-bis(amino-2-pyridyl)-2,2'-bipyridine $\left.)(\mathrm{NCS})_{2}\right]$.

Figure 37. Schematic diagram of [ $\left\{\mathrm{Fe}(2,6-\text { bis(pyrazol-3-yl)pyridine })(\mathrm{NCS})_{2}\right\}_{2}\left(4,4^{\prime}\right.$-bipy) $]$.

Figure 38. Schematic diagram of [Fe( $N$-2'-pyridylmethylene-4-(phenylazo)-aniline $\left.)_{2}(\mathrm{NCS})_{2}\right]$. 
Figure 39. Schematic diagram of [Fe( $N$-2'-pyridylmethylene-4-aminobiphenyl $\left.)_{2}(\mathrm{NCS})_{2}\right]$.

Figure 40. View of the $\mathrm{Mn}_{6}$ core and coordinated donor atoms in $\left[\mathrm{Mn}_{6} \mathrm{O}_{2}(2-\right.$ hydroxyphenylpropanone $\left.)_{6}(\mathrm{~L})_{2}(\mathrm{EtOH})_{6}\right]\left(L=\mathrm{O}_{2} \mathrm{CPh}(\mathrm{Me})_{2}\right.$, naphthalene carboxylate). $\mathrm{Mn}$ atoms are in purple and larger, $\mathrm{N}$ atoms in pale blue, $\mathrm{O}$ atoms in red.

Figure 41. Schematic diagram of $\left[\mathrm{Mn}_{3}(\text { cis,cis-1,3,5-cyclohexanetriol })_{2}(2,2 \text { '-bipyridine })_{4}\right]^{3+}$.

Figure 42. View of the $\mathrm{Mn}_{12}$ core and coordinated donor atoms in $\left[\mathrm{Mn}_{12} \mathrm{O}_{12}\left(\mathrm{O}_{2} \mathrm{CCH}_{2}{ }^{\mathrm{t}} \mathrm{Bu}\right)_{16}\left(\mathrm{H}_{2} \mathrm{O}\right)_{4}\right]$. The Jahn-Teller axis that is misaligned perpendicular to the other axes at ambient pressure is highlighted. Mn atoms are in purple and larger, $\mathrm{O}$ atoms in red.

Figure 43. Schematic diagram of $\left[\mathrm{Mn}_{2} \mathrm{O}_{2}\left(2,2^{\prime} \text {-bipyridine }\right)_{4}\right]^{3+}$.

Figure 44. Schematic diagram of the chain formation of the inorganic anion in the antiferromagnet $\left[\left(\mathrm{CH}_{3}\right)_{4} \mathrm{~N}\right]\left[\mathrm{MnCl}_{3}\right]$.

Figure 45. Schematic diagram of $\left[\mathrm{Mn}(\mathrm{II})(\right.$ pyridazine $\left.)\left(\mathrm{H}_{2} \mathrm{O}\right)_{2}\right]\left[\mathrm{Mn}(\mathrm{II})\left(\mathrm{H}_{2} \mathrm{O}\right)_{2}\right]\left[\mathrm{Nb}(\mathrm{IV})(\mathrm{CN})_{8}\right]$.

Figure 46. Overlay view of the pyridazine ring and coordination spheres of the metal centres involved in $\left[\mathrm{Mn}(\mathrm{II})(\right.$ pyridazine $\left.)\left(\mathrm{H}_{2} \mathrm{O}\right)_{2}\right]\left[\mathrm{Mn}(\mathrm{II})\left(\mathrm{H}_{2} \mathrm{O}\right)_{2}\right]\left[\mathrm{Nb}(\mathrm{IV})(\mathrm{CN})_{8}\right]$ to show the pressure-induced rotation of the plane of the ring.

Figure 47. Schematic diagram of BEDT-TTF (BEDT-TTF = bis(ethylenedithio)tetrathiafulvalene), the organic component of the systems described in Sections 6.1, 6.2 and 6.3.

Figure 48. Schematic diagram of the networks formed by $\mathrm{Cu}(\mathrm{NCS})_{2}$ in $\kappa-\left[(\mathrm{BEDT}-\mathrm{TTF})_{2} \mathrm{Cu}(\mathrm{NCS})_{2}\right](\mathrm{BEDT}-$ $\mathrm{TTF}=$ bis(ethylenedithio)tetrathiafulvalene). The orthogonal $\mathrm{S} \cdots \mathrm{C}$ interaction in the centre of the Figure is shown as a hashed linkage.

Figure 49. Schematic diagram for $\left[\mathrm{M}(\mathrm{dpg})_{2}\right]\left(\mathrm{M}=\mathrm{Ni}, \mathrm{Pt} ; \mathrm{dpg}^{-}=\right.$diphenylglyoximate $)$and $\left[\mathrm{Pt}(\mathrm{dmg})_{2}\right]\left(\mathrm{dmg}^{-}\right.$ = dimethylglyoximate).

Figure 50. Schematic diagram of $\left[\operatorname{Pd}(1,3-\text { dithiole-2-thione-4,5-dithiolate })_{2}\right]^{0.5-}$.

Figure 51. Schematic diagram of $\left[\mathrm{Au}(\mathrm{tmdt})_{2}\right]\left(\mathrm{tmdt}^{2-}=\right.$ trimethylenetetrathiafulvalenedithiolate). 